\title{
COMPETITION AND STABILITY IN BANKING
}

\author{
Xavier Vives
}


The Public-Private Sector Research Center is a Research Center based at IESE Business School. Its mission is to develop research that analyses the relationships between the private and public sectors primarily in the following areas: regulation and competition, innovation, regional economy and industrial politics and health economics.

Research results are disseminated through publications, conferences and colloquia. These activities are aimed to foster cooperation between the private sector and public administrations, as well as the exchange of ideas and initiatives.

The sponsors of the SP-SP Center are the following:

- Accenture

- Ajuntament de Barcelona

- Caixa Manresa

- Cambra Oficial de Comerç, Indústria i Navegació de Barcelona

- Consell de l'Audiovisual de Catalunya

- Departament d' Economia i Finances de la Generalitat de Catalunya

- Departament d' Innovació, Universitats i Empresa de la Generalitat de Catalunya

- Diputació de Barcelona

- Endesa

- Fundació AGBAR

- Garrigues

- Mediapro

- Microsoft

- Sanofi Aventis

- ATM, FGC y TMB

The contents of this publication reflect the conclusions and findings of the individual authors, and not the opinions of the Center's sponsors. 


\title{
COMPETITION AND STABILITY IN BANKING*
}

\author{
Xavier Vives ${ }^{1}$
}

\section{Abstract}

I review the state of the art of the academic theoretical and empirical literature on the potential trade-off between competition and stability in banking. There are two basic channels through which competition may increase instability: by exacerbating the coordination problem of depositors/investors on the liability side and fostering runs/panics, and by increasing incentives to take risk and raise failure probabilities. The competitionstability trade-off is characterized and the implications of the analysis for regulation and competition policy are derived. It is found that optimal regulation may depend on the intensity of competition.

\footnotetext{
${ }^{1}$ Professor of Economics, Abertis Chair of Regulation, Competition and Public Policy, IESE
}

\footnotetext{
* Public-Private Sector Research Center, IESE Business School. This paper has been prepared for the Thirteenth Annual Conference of the Central Bank of Chile "Monetary Policy under Financial Turbulence", Santiago de Chile, November 2009. I am grateful to an anonymous referee for useful comments and to Jorge Paz for his helpful research assistance. The research leading to these results has received funding from the European Research Council under the European Advanced Grants scheme, project Information and Competition, Grant Agreement no. 230254. I also thank the Abertis Chair of Regulation, Competition and Public Policy, project EC02008-05155 of the Spanish Ministry of Education and Science at the Public-Private Sector Research Center at IESE.
} 


\title{
Competition and Stability in Banking
}

\author{
Xavier Vives* \\ IESE Business School
}

January 2010

\begin{abstract}
I review the state of the art of the academic theoretical and empirical literature on the potential trade-off between competition and stability in banking. There are two basic channels through which competition may increase instability: by exacerbating the coordination problem of depositors/investors on the liability side and fostering runs/panics, and by increasing incentives to take risk and raise failure probabilities. The competition-stability trade-off is characterized and the implications of the analysis for regulation and competition policy are derived. It is found that optimal regulation may depend on the intensity of competition.
\end{abstract}

* Public-Private Sector Research Center, IESE Business School. This paper has been prepared for the Thirteenth Annual Conference of the Central Bank of Chile "Monetary Policy under Financial Turbulence”, Santiago de Chile, November 2009. I am grateful to an anonymous referee for useful comments and to Jorge Paz for his helpful research assistance. The research leading to these results has received funding from the European Research Council under the European Advanced Grants scheme, project Information and Competition, Grant Agreement no. 230254. I also thank the Abertis Chair of Regulation, Competition and Public Policy, project ECO2008-05155 of the Spanish Ministry of Education and Science at the Public-Private Sector Research Center at IESE. 


\section{Introduction}

Banking went from being one of the most regulated sectors in the economy after the crisis in the 1930s to a much more lightly regulated sector with the liberalization process started in the 1970s in the US. The first period was market by few crises while there has been much more instability in the second one, culminating with the 2007- subprime crisis. In the first period competition was thought to be detrimental to stability and in many countries competition policy was not applied fully to the sector until recently despite the importance of the banking sector in the economy and the costs and inefficiencies induced by financial repression. Indeed, until relatively recently central banks and regulators were complacent with collusion agreements among banks and preferred to deal with a concentrated sector with soft rivalry.

This changed with deregulation and the idea that competition enhances efficiency, be it productive, allocative, or dynamic (innovation). Competition policy is now taken seriously in the banking sector. ${ }^{1}$ However, the crisis started in 2007 with subprime mortgages, becoming systemic after the demise of Lehman Brothers in September 2008, with cumulative banking losses estimated as 1,1 trillion $€$ (up to November 2009) and massive bailouts (state aid with commitments in public interventions in the EU and US) of up to $30 \%$ of GDP, has overridden competition policy concerns. Indeed, the public help programs have distorted competition and created an uneven playing field in terms of the cost of capital and perception of safety and soundness. Market power concerns on mergers have been also overruled. In the UK Lloyds TBS took over the troubled HBOS (merger of Halifax and Bank of Scotland) in a merger opposed by the Office of Fair Trade creating a large entity, while the same Lloyds TBS had not been allowed to take over Abbey in 2001. The investment banking business has been consolidated in the US with the forced takeovers of Bear Sterns by JP Morgan and of Merrill Lynch by Bank of America. The result is potentially weak competition among the players left. Those

\footnotetext{
1 In the US banking becomes subject to competition law in the 1960s with the end of its antitrust exemption. In the EU the European Commission has intervened since the 1980s against a range of restrictive practices, in mergers and in state aid. See Carletti and Vives (2009).
} 
consolidations add to the recent trend of increased consolidation within countries, across countries and across business lines (e.g. forming financial conglomerates). ${ }^{2}$

Banking and financial markets display the whole array of classical market failures, due to externalities (fragility with coordination problems and contagion), asymmetric information (excessive risk taking with agency problems, moral hazard and adverse selection), and potential market power. This has led to regulation to protect the system, the small investor, and market competitiveness. The problem is that facilities like the lender of last resort, deposit insurance and "too big to fail" policies introduce further distortions and exacerbate the excessive risk taking problem. In fact, the crisis has uncovered massive regulatory failure as well and potential contradiction between regulatory intervention and competition policy.

This paper takes stock of what we know on the relationship between competition and stability, and suggests how to deal with the interplay of regulation and competition issues in banking in the aftermath of the systemic crisis started in 2007.

The plan of the paper is as follows. Section 2 examines the trends in the banking sector and in its regulation, taking into account the impact of the crisis. Section 3 explains the uniqueness of banks, why the banking system is fragile and the role of regulation. ${ }^{3}$ Section 4 examines the trade-off between competition and stability in banking from a theoretical perspective both from the point of view of fragility and of potential excessive risk taking. Section 5 surveys the empirical evidence available. Section 6 ponders whether we can regulate away the competition-stability trade-off. Section 7 examines the policy response to the crisis and summary and concluding remarks close the paper.

\footnotetext{
2 See, e.g. Group of Ten (2001).

3 Sections 2 and 3 are partially based on Vives (2001, 2006).
} 


\section{Trends in the banking sector}

Two periods can be distinguished in the recent history of the financial sector: Tight regulation, intervention, and stability, from the 1940s up to the 1970s, followed by a period marked by liberalization and greater instability. (See Figure 1.)

From the 1940s to the 1970s, competition between financial institutions was severely limited by the regulation of rates, activities, and investments, the separation between commercial banking, insurance, and investment banking (Glass-Steagall Act of 1933 in the US) ${ }^{4}$, restrictions on the activity of the savings banks, and geographical segregation (in the US). Universal banking remained in some European countries. Deposit insurance was established, and the central bank acted as lender of last resort to the financial system.

The stability of this earlier period contrasts with the sizeable increase in the number of failures and crises in the later period, in which the sector was liberalized and competition introduced. ${ }^{5}$ International evidence points at liberalization as one of the factors, together with inadequate macro policies, adverse macro shocks, and vulnerability of the foreign sector, to explain banking crises. That is, liberalization, even controlling for a wide range of factors, increases banking fragility. There are also strong indications that the institutional environment (e.g., in terms of the rule of law and contract enforcement) and inappropriate regulation that accompanies liberalization reinforce the development of crises. ${ }^{6}$ This is consistent with banking crises in diverse places like the US (S\&Ls), Japan, Scandinavia and Spain. In all those cases regulatory failure seems to have played an important role in the crisis. ${ }^{7}$ Despite the crises episodes financial liberalization has helped in general financial development, and therefore output growth.

4 The Glass-Steagall Act prohibited any one institution from acting as any combination of an investment bank, a commercial bank, and/or an insurance company.

5 See Reinhart and Rogoff (2008a, b).

6 See, for example, Demirgüç-Kunt and Detragiache (1998, 2001)).

7 See Dewatripont and Tirole (1994) for the US case and Hoshi and Kayshap (2000) for Japan. In both cases increased competitive pressures on financial institutions (e.g. competition from nonbank intermediaries allowed by deregulation) leads to overexpansion in risky lines of business (e.g. real state) which are not checked because of lax supervision and regulatory forbearance together with implicit protection of entities in trouble, In Scandinavia the roots of the early 1990s crisis are to be found in a conjunction of factors after the financial liberalization of the 1980's: lax enforcement of 


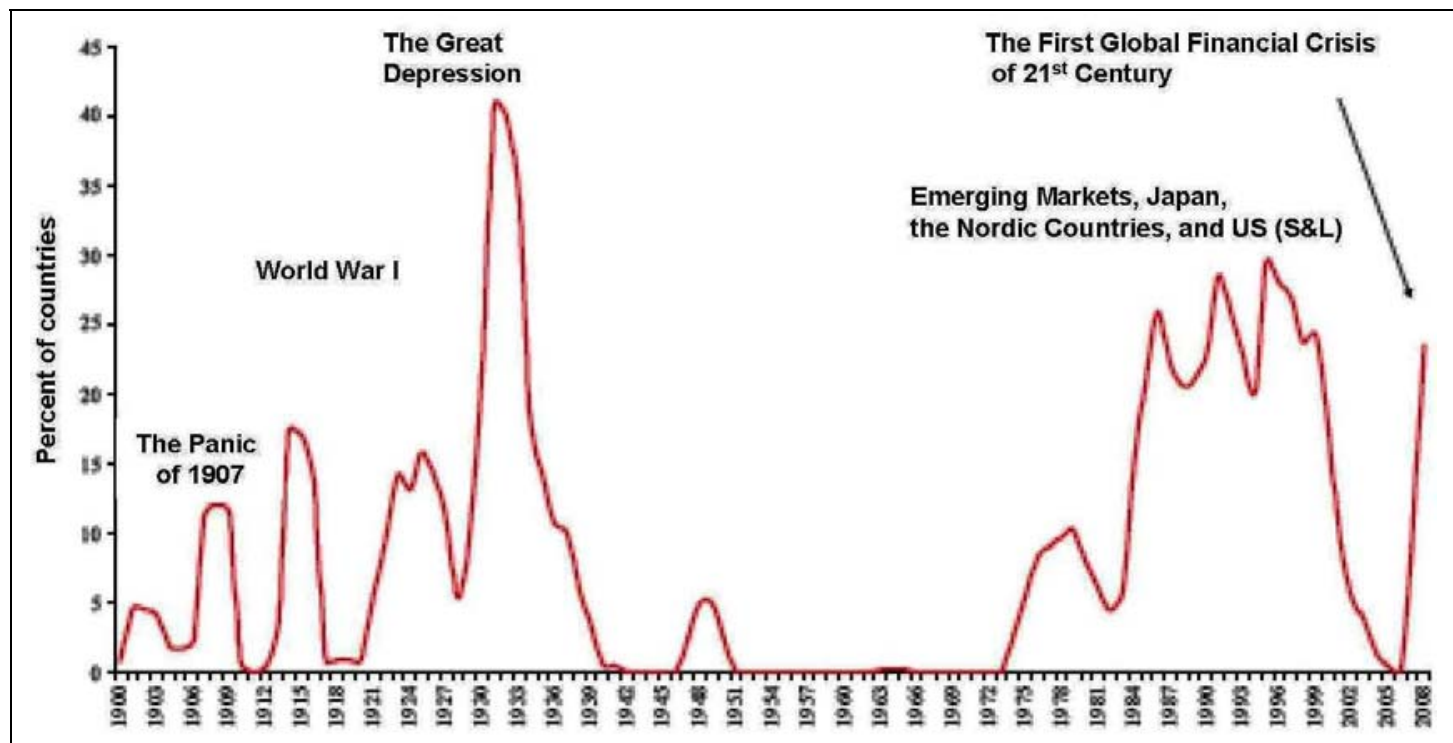

Figure 1. Proportion of countries with banking crises: 1900-2008, weighted by their share of world income. Source: Figure 1 in Reinhart and Rogoff (2008a).

Liberalization consisted on the lifting of controls on rates and on banking investment activities, and of geographical restrictions (with the Riegle-Neal Act in the US in 1994), the elimination of compulsory investment coefficients, and the convergence between the activities of institutions of various types (e.g. between savings banks and ordinary banks, between commercial banking and investment banking -definite repeal of Glass-Steagall Act with the Financial Services Modernization Act in 1999, between banking and insurance -up to a point). ${ }^{8}$ Behind the process of liberalization and deregulation we find advances in information technology, in the processing of transactions (automatic teller machines, telephone and electronic banking), and in computational capacity, as well as in management techniques and risk coverage (e.g. the use of derivative instruments and securitization techniques). An integral part of the process was the liberalization of

capital requirements, poor supervision, lack of internal risk control methods, together with mistakes in fiscal and monetary policy in the context of an asset price bubble (See, e.g., Honkapohja (2009).) In Spain financial liberalization started in the 1970s and the banking crisis of the first half of the 1980s is explained by the large impact of the economic crisis derived from the oil shocks, the close links of banks with industrial firm, lack of diversification of banks' industrial portfolios, bad management and inadequate supervision (see Caminal, Gual and Vives (1990)).

8 For example, Citicorp (a commercial bank holding company) merged with Travelers Group (an insurance company) in 1998 to form the conglomerate Citigroup. 
international capital movements and the general reduction in transport costs and barriers to trade; financial globalization, in short.

The result of the liberalization process has been an increase in competition, both within and from outside the banking industry, with banks facing direct competition from financial markets and the development of disintermediation and financial innovation. Market integration (in Europe and elsewhere) has contributed decisively to the increase in competition in wholesale and investment banking. Interestingly, the share of assets held by banks relative to non-bank financial intermediaries is declining in developed economies (in the US up to 2007) although banks assets are not declining relative to total financial assets because the share of non-bank intermediaries grows at the expense of directly held assets. ${ }^{9}$ (See Figure 2.)

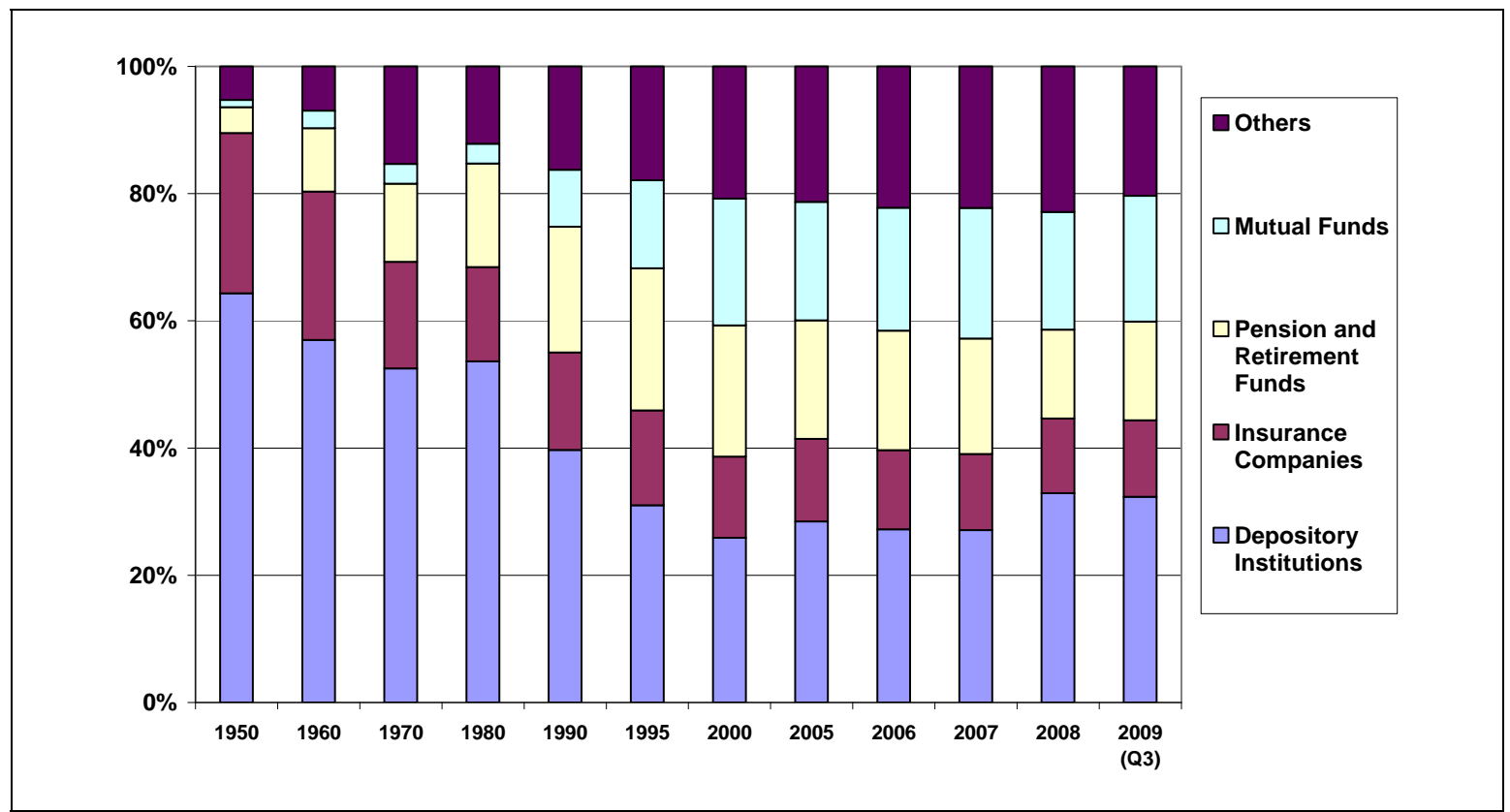

Figure 2: Distribution of US financial assets by the main types of financial intermediaries. Source: Barth et al. (1997), and updated data from Flow of Fund Accounts, Board of Governors of the Federal Reserve System.

The liberalization process has resulted also in a tremendous expansion of financial intermediation with financial assets of intermediaries increasing sharply as a percentage

$9 \quad$ See also Berger, Kashyap, and Scalise (1995) and Allen and Santomero (2001). 
of GDP (in the US the percentage goes from less than 100\% in 1950 to a peak of more than $300 \%$ in 2007 , with assets in banks going from $50 \%$ to $100 \%$ in the same period, see Figure 3).

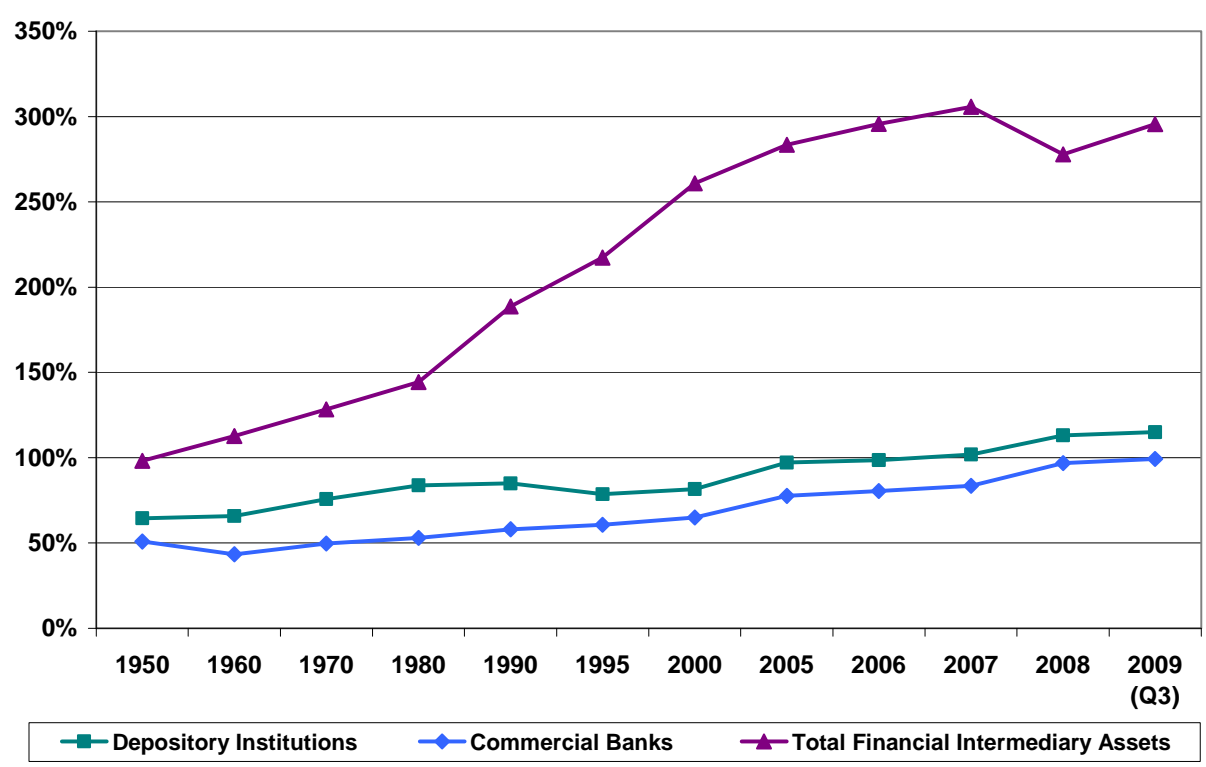

Figure 3. Relative size of the US financial sector and the banking industry (Financial assets/GDP). Source: "Flow of Funds Accounts", Board of Governors of the Federal Reserve System.

This effective expansion of the financial market has implied that even banking, in spite of the advance of disintermediation, has grown in real terms (see Figure 4). 


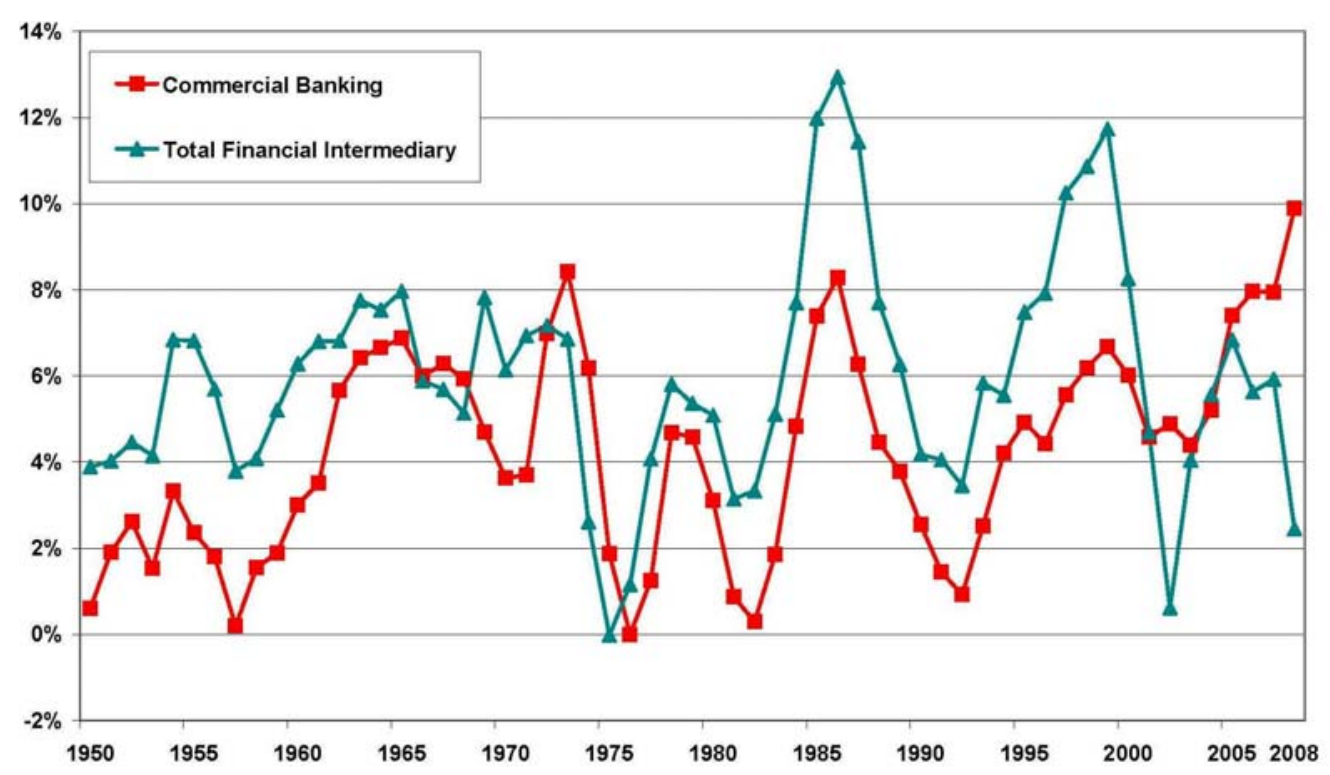

Figure 4. Growth Rates in U.S. Real Financial Assets (Three year moving average: 1950-2008). Source: Federal Reserve Board of Governors.

Before the 2007 crisis banking was evolving from the traditional business of taking deposits and granting (and monitoring) loans to the provision of services to investors (investment funds/asset management, advice and insurance) and firms (consulting, insurance, mergers and acquisitions, underwriting of equity and debt issues, securitization, risk management), and proprietary trading. In a financial conglomerate we can distinguish a retail bank, an investment or corporate bank, asset management, proprietary trading, and insurance. The infamous model of "originate and distribute" banking, where banks try to get rid of credit risk by originating mortgage loans and quickly securitizing them leaving the monitoring of mortgages in a limbo, is a good example of the evolving banking process. At the same time even if banks created offbalance sheet vehicles (SIV, ABCP conduits) in the end they were insuring them with liquidity lines. In any case the financial margin made way for fee and commission revenue and there was a switch from investment in bricks and mortar (the branches) to investment in communication networks, information technology, and highly specialized human capital. Post crisis the financial margin has gained again importance (if nothing else because of the very low or zero interest rate policy of central banks) and the share of banks' assets in financial assets is up from pre-crisis levels (see Figure 2). The return to 
traditional banking is seen also in Figure 4 where recently commercial banking grows more than total financial intermediaries in real assets.

Restructuring is taking the form of consolidation, with similar declines in the US and Europe on the number of banks in 1997-2007 (22\% decline in the US and a 29\% decline in EU-15). In Europe there has been a predominance of domestic and, more recently, cross-border, mergers ${ }^{10}$ and in the US of interstate mergers. A consequence is that despite an increase in national concentration at the US level in the last twenty years (see Figure 5 for assets) local concentration (measured in MSA and non-MSA counties for deposits) ${ }^{11}$ shows, if anything, a decreasing tendency (Berger, Demsetz and Strahan (1999), Table 7 in White (2009)).

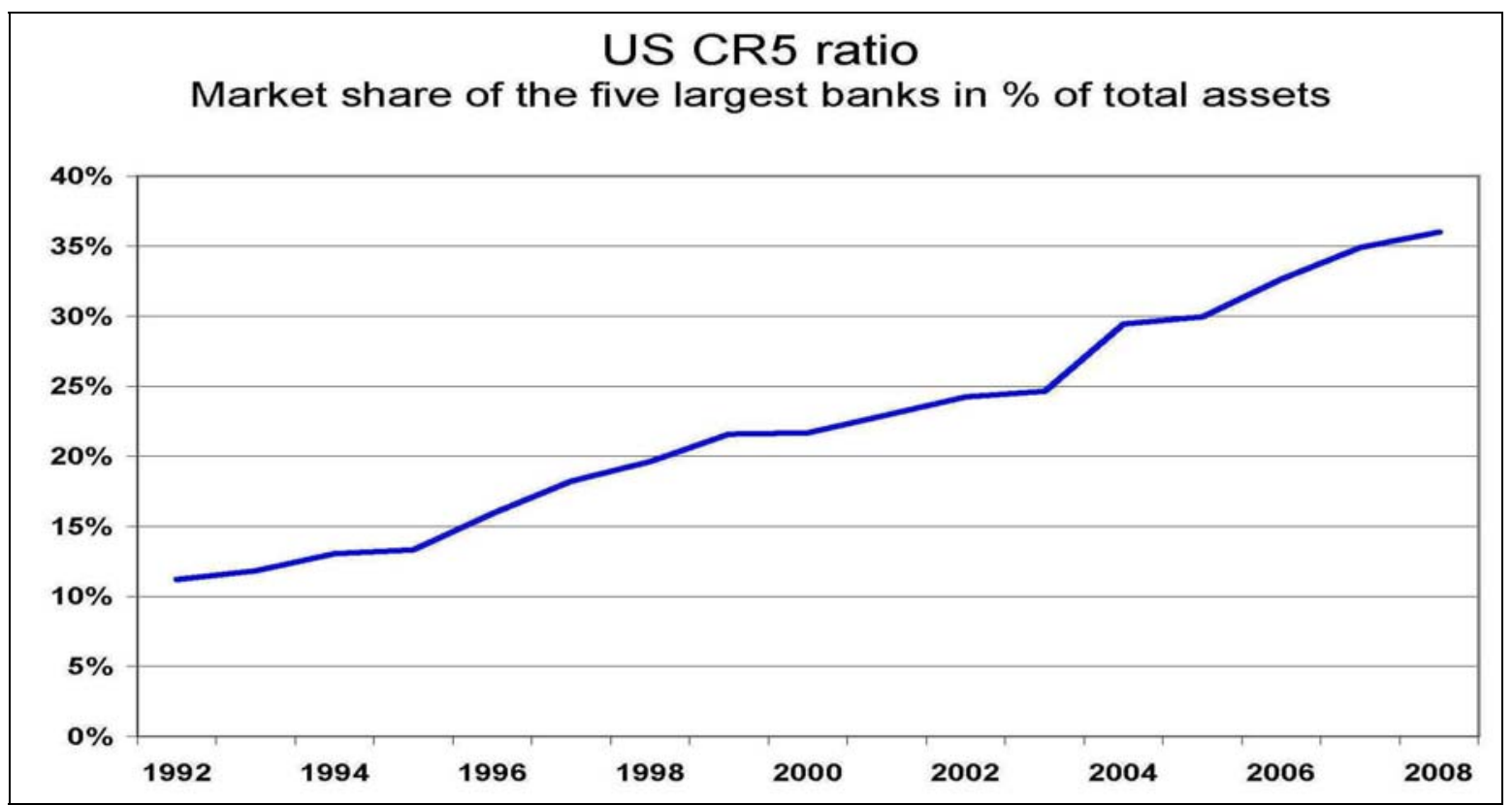

Figure 5. US CR5 ratio. Share of the five largest depositary institutions in \% of total assets ${ }^{12}$ Source: FDIC and Federal Reserve.

10 For example, Hypobank-Vereinsbank in Germany, UBS-SBC in Switzerland, BNP-Paribas in France, IMI-San Paolo and Crédito Italiano-Unicrédito in Italy, Santander-BCH to form BSCH and BBVArgentaria to form BBVA in Spain. Exceptions are some cross-border deals in the Benelux and Scandinavia. Some cross-border mergers have failed because of political interference of national authorities. See Danthine et al. (1999).

11 Metropolitan Statistical Areas (MSAs) are used as proxies for urban local markets while non-MSAs are used as proxies for rural local markets).

12 The merger of Wells Fargo and Wachovia is accounted for in 2008. 
In Europe the dominance of domestic mergers tends to increase local concentration (e.g., in 19 over $27 \mathrm{EU}$ markets the CR5 in assets is above 50\% in 2007). ${ }^{13}$ (See Figures 6, 7 for the EU-15).

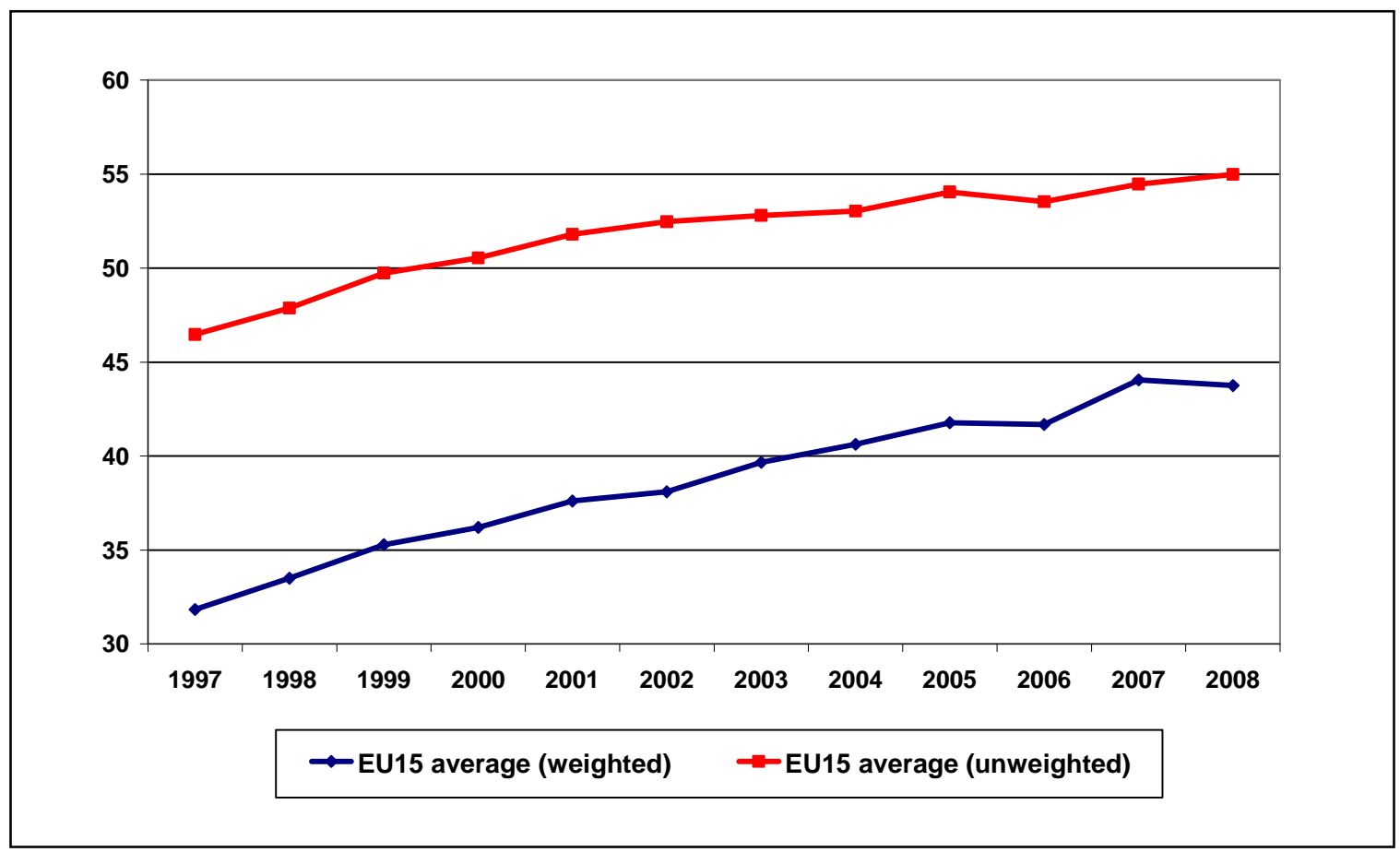

Figure 6. Share of CR5 in \% of total assets. Source: ECB (2006, 2007, 2008).

13 See Schildbach (2009) for the US. 


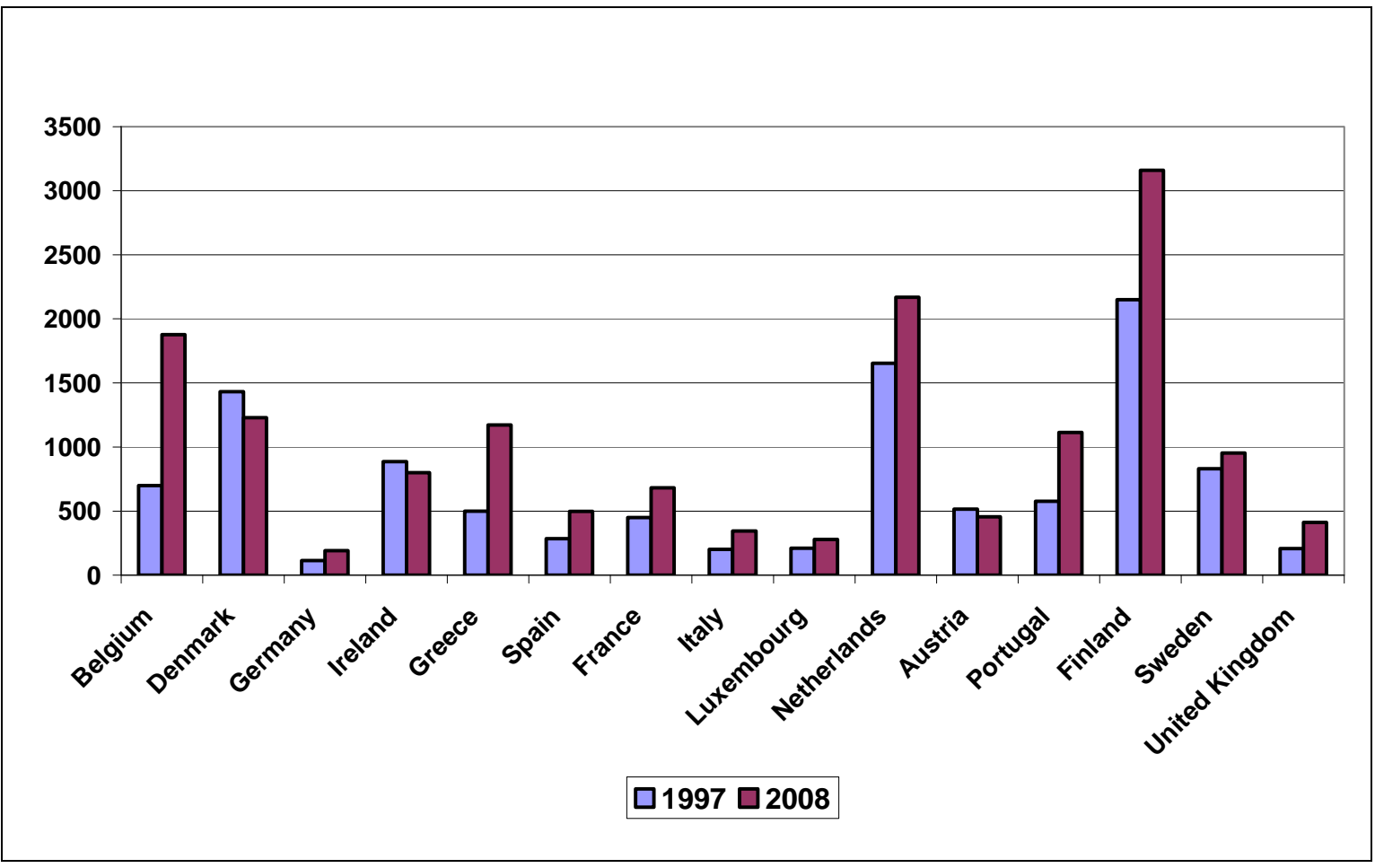

Figure 7: Herfindahl index (total assets). Source: ECB (2004, 2008)

In the US the CR-5 ratio for assets has increased in 2008 to 36\% (with several pots crisis operations including JP Morgan-Washington Mutual and Wells Fargo-Wachovia) from a level of $23 \%$ in $2001 .{ }^{14}$ This contrasts with the movement in EU-15 from 52\% to 54.5\% (unweighted average) and from $37.6 \%$ to $44 \%$ (weighted average) in the same period. ${ }^{15}$

In summary, liberalization has been associated with an increase in competition faced by financial intermediaries, but bank assets have not declined in relation to total financial assets, and with an increase in the incidence of crises. At the same time, banking has transformed itself towards services provision and restructuring has tended to increase aggregate concentration (although the consequences of this may have been different in relevant retail local markets in the US and Europe). The crisis marks a return to traditional banking and tends to exacerbate the consolidation trend.

14 From 2000 to 2008 the CR-10 ratio for deposits goes from 36\% to almost 51.5\%.

15 See Schildbach (2009) for the US. 
The introduction of competition in banking has been accompanied by checking risk taking with capital requirements, allowing banks to rely on their own internal models to assess and control risk, and including disclosure requirements for financial institutions in order to increase transparency and foster market discipline. A flexible view of capital requirements ${ }^{16}$, supervision, and market discipline are the pillars of the Basel II framework. The rationale of the reformed framework was to provide more risk sensitivity to capital requirements. Supervisors would assess how well banks are matching their capital to the risks assumed and banks would disclose information on its capital structure, accounting practices, risk exposures and capital adequacy. In summary, capital requirements plus appropriate supervision and market discipline were seen as the main ingredients to maintain a sound banking system. All this is under revision because of the crisis.

\section{The role of banks, fragility and regulation}

Banks provide transaction and payment system services, insurance, and risk sharing (transforming illiquid assets into liquid liabilities). A central function of banks is the financing and monitoring of entrepreneurial projects which are illiquid and opaque because of asymmetric information problems like adverse selection and moral hazard. A lender needs relationship-specific skills to collect those loans that are illiquid because the financed projects are opaque. Indeed, a main function of the banking and financial system is to help to overcome problems associated with asymmetric information in an economy.

\subsection{Fragility and the uniqueness of banks}

The essence of banks is that they create liquidity and this leaves them vulnerable to runs. Banks protect entrepreneurs from the liquidity needs of depositors/investors. There are different versions of the story but this is the building stone of modern banking theory (Diamond and Dyvbig (1983), Holmstrom and Tirole (1997, 1998), Diamond and Rajan (2001)). The demand deposit contract, redeemable at par, creates a coordination problem

16 Allowing banks to choose from a menu of approaches (for example, standardized and internal rating) to measure risk (credit, market and operational). 
for investors that either allows the banker not to extort rents on his abilities to collect illiquid loans (Diamond and Rajan (2001)) or disciplines bank managers subject to a moral hazard problem (Calomiris and Kahn (1991), Gale and Vives (2002)). Because of asymmetric information firms may get no funding because they do not have enough pledgeable income (fraction of their return that can be committed to be paid to outsiders). Banks come to the rescue, for example, by creating liquidity holding collateral and committing to make payments (Holmstrom and Tirole $(1997,1998)$ ). In short, the standard deposit contract and loan provision to opaque entrepreneurial projects are complementary and central to the function of a bank.

At the base of the fragility of banking there is a coordination problem of investors, who may decide to call back their short-term deposits or CDs and make a sound bank fail. The literature has presented two views of crises: the multiple equilibrium panic view (Bryant (1980), Diamond and Dyvbig (1983)) and the information-based view (Gorton (1985, 1988) and Jacklin and Battacharya (1988)). According to the former, runs are triggered by sunspots, i.e. by events unrelated to the fundamentals, while according to the latter runs are triggered by bad news on the assets of the bank. Recently those views have been reconciled introducing asymmetric information and linking the probability of a run to the strength of fundamentals (Goldstein and Pauzner (2005), and Rochet and Vives (2004)). ${ }^{17}$ (In Section 4.1 I will examine the impact of competitive pressure on instability in this context.) We have thus that a solvent bank may be subject to a panic, depositors withdrawing the funds invested and the bank being forced to quickly liquidate assets at a penalty. The cause of the problem is the dependence of banks on short-term debt.

In addition, there is the danger of systemic risk owing to contagion from the failure of an entity, which may give rise to a strong negative externality both for the financial sector and for the real sector of the economy. For example, the failure of one entity may, through interbank market commitments, lead to that of others (see Allen and Gale (2000)). Similarly, large variations in the price of assets such as an abrupt fall in the stock

17 Postlewaite and Vives (1987) provided an early model with a unique equilibrium where the probability of a crisis is determined by the realization of the liquidity needs of depositors, which are private information. 
market, or the failure of a major intermediary, may generate a domino effect and systemic crises affecting the payment system. ${ }^{18}$

Crises, however, may have positive aspects and in some circumstances be optimal from an ex ante point of view by making payment to depositors contingent on returns and improving risk sharing (Alonso (1996), Allen and Gale (1998)) or helping control the incentives of the banker (Calomiris and Kahn (1991), Gale and Vives (2002)). For example, in the presence of a moral hazard problem incentive efficiency requires that the expected utility of investors/depositors be maximized subject to the constraint that the bank manager exerts effort. This can be accomplished by liquidating the project when observable interim returns are lower than a certain threshold (this is the minimal threshold that induces the manager to exert effort, a higher threshold would just increase the costs associated to liquidation). The threat of liquidation disciplines banks managers but typically there is excessive liquidation and fragility (i.e. "excessive" coordination failure - Rochet and Vives (2004)). The reason is that competitive banking will typically reward investors over and above the level which imply the optimal threshold for liquidation. The challenge of regulation and supervision is to induce an incidence of crises just enough to keep the right incentives of bankers taking into account the degree of competition in the market (we will return to this question in Section 6).

In summary, banks are unique because of their particular mix of features: High (short term) leverage, dispersed debtholders (implying a low level of monitoring), with opaque bank assets of long maturity which exacerbate moral hazard problems, fragile with a high social cost of failure, and subject to contagion (via interbank commitments or indirect market-based balance sheet linkages) with potentially systemic impact. At the same time banks have a central position in the economic system, they are indeed essential, when banks stop functioning a modern monetary economy stops.

18 System-wide runs were usual in the US in the XIX century and the beginning of the XX century. More recently they have occurred in Brasil in 1990, Ecuador in 199), and Argentina in 2001. 
The situation may be even worse in an emerging economy where the role of banks is relatively more important since asymmetric information problems are bound to be more acute and financial markets less developed. Banks and their monitoring capacity are therefore at the center stage of economic development and their potential fragility may worsen downturns dramatically.

\subsection{Market failures and regulation}

Financial markets display the whole range of the major market failures: externalities, asymmetric information, and market power.

The inherent fragility in the banking system leads to the failure of institutions, panics, and systemic crises that potentially have a major impact because of economy-wide externalities. The great depression of the 1930s and the subprime crisis are good examples, as well as the episodes of financial crisis in the US, Scandinavia, Mexico, East Asia and Russia, and remind us of the potential for severe economic disruption. The failure of a bank has adverse consequences on non-financial firms precisely because individual bank-firm relationships are valuable (Petersen and Rajan (1994)). In fact, even a contraction of bank capital may induce a credit crunch with severe disruption to the private sector. A major market failure is therefore the lack of internalization by financial intermediaries of the social cost of bankruptcy and potential systemic risk. Contagion may obtain because of network effects in the payment system, interbank market, or derivatives markets. Market liquidity and funding liquidity may interact causing downward spirals. ${ }^{19}$

Asymmetric information is in fact the raison d'être of financial intermediaries. However, as we will see in Section 4.2 the agency problem in a bank leads to excessive risk taking because of moral hazard and risk-shifting incentives. Adverse selection in credit and financial markets may lead to the failure of competition and even market breakdown. The small investor is left unprotected if the market is not regulated.

19 See Brunnermeier and Pedersen (2009) for a model of a liquidity spiral combining market and funding liquidity. 
Imperfect competition is the norm and not the exception in banking. Very important frictions prevent banking from being perfectly competitive. Indeed, asymmetric information creates barriers to entry or makes competition not to deliver efficient outcomes. An example may be provided by credit rating agencies where conflicts of interest due to the issuer-pays model, entry restrictions, and a failure of the reputation mechanism seems to lead to a race to the bottom. Other sources of frictions are switching costs, network effects (in retail banking, credit cards, or markets in general) and the ubiquity of two-sided competition in the banking sector.

Competitive banking will be in general excessively fragile and lender of last resort (LOLR) facilities, deposit insurance, "too big to fail" policies, and prudential regulation come to the rescue. They protect the system against negative economy-wide externalities. The aim of regulation has been to provide the banking and financial systems with stability to avoid the negative effects associated with failing institutions and systemic crises. Regulation also aims to protect the small investor. Other policies are established to promote the competitiveness of the system and to maintain competitive markets (competition policy).

Financial regulation is not without side effects. The most important one is the potential moral hazard induced by protection and bail outs extended to failing institutions. (We will come back to this issue in Sections 4.2 and 6 where we will see the effects of regulatory pitfalls.) The LOLR and deposit insurance are two of the basic instruments on which the stability of the banking system rests. However, often blanket insurance is offered to banks and depositors according to the too-big-to-fail (TBTF) policy. The TBTF policy is justified usually on the potentially systemic consequences of the failure of a large institution, but help may be a reflection of a problem of time-inconsistency. In the presence of a moral hazard problem in the banking sector (say, the level of effort in monitoring projects by the banker) a well-intentioned regulator will find it optimal ex post to help whenever this salvages the value of projects. Bankers, anticipating the help, will tend to exert suboptimal effort (see Gale and Vives (2002)). This is an instance of the timeinconsistency problem faced by a central bank, for example. Ex post, costly liquidation of 
the projects will not be optimal, so the central bank may be soft. The commitment problem is compounded by the interest of a bank manager in the continuation of the bank. Building a central bank with a "tough” reputation can alleviate the time-inconsistency problem. Similarly, suspension of convertibility may remove incentives of depositors to run (Diamond and Dybvig (1983)) but if the banking authority can not pre-commit to such a deposit freeze and uses an ex-post efficient (softer) intervention then runs will be encouraged (Ennis and Keister (2009)).

In emerging markets asymmetric information problems are more acute and the reliance on the banking system to try to overcome them more important. On top these economies face a more severe policy commitment problem that leads to excessive bailouts and potential devaluation of claims of foreign investors. This exacerbates the moral hazard problem and provides a reason for importing external discipline (for example, acquiring foreign short-term debt). However, external discipline may come at the cost of excessive liquidation of entrepreneurial projects (the tradeoffs involved are examined in Vives (2006)).

\section{Competition and stability}

Competition may influence stability basically through the liability or through the asset side of the balance sheet of a financial intermediary. In particular, competition may increase instability by (1) exacerbating the coordination problem of depositors/investors on the liability side and fostering runs and/or panics which may be of systemic nature, and (2) increasing the incentives to take risk (on either the liability or asset sides) and raise failure probabilities. I will examine those possibilities in turn. For (1) I will sketch a model since it is a point not yet well understood.

\subsection{Competition, runs and fragility}

The first thing to notice is that competition is not responsible for fragility. Indeed, vulnerability to runs may emerge independently of market structure. This result is obtained by Matutes and Vives (1996) in a model which combines the banking model of 
Diamond (1984) with a differentiated duopolistic structure à la Hotelling. In the model the probability of failure of a bank is determined endogenously by the expectations of depositors. Those are self-fulfilling due to diversification-based scale economies: a bank which is perceived to be safer commands a larger margin and attracts a higher market share allowing a better diversification. The model admits multiple equilibria with corner solutions where only one bank is active or an equilibrium where no bank is active like in a systemic confidence crisis. This arises due to the coordination problem between depositors (much as in the network externalities literature) and its presence does not depend on market structure. A monopoly bank may suffer a run. However, an increase in rivalry does increase the probability of failure in an interior equilibrium of the depositor's game where banks have positive market shares. ${ }^{20}$

Chang and Velasco (2001) present a model of financial crisis in emerging markets in the Diamond and Dybvig (1983) tradition and find that financial liberalization increases the expected welfare of depositors but may increase also fragility. Liberalization is modeled as moving from a monopoly to a competitive situation. A monopolist bank holds depositors to their reservation level which implies that they are kept indifferent to an autarchic system with no financial intermediation. The monopolist bank does so by reducing payments to depositors and therefore its short-run liabilities. Profits act as a buffer against unexpected withdrawals. The consequence is that the bank is less likely to fall in the range where a self-fulfilling crisis occurs than in a competitive situation. Furthermore, monopoly banking has to deliver a lower level of welfare since a competitive bank maximizes the ex ante utility of depositors, taking into account the probability of a run according to an exogenous sunspot probability, and autarchy is a feasible allocation. ${ }^{21}$

The recent reconciliation of the self-fulfilling theory of crises with the information and fundamentals driven view delivers insights into the competition-stability relationship

20 Smith (1984) links instability in a model à la Diamond and Dybvig (1983) to the non-existence of equilibrium.

21 Todd Keister has raised a similar point when discussing the paper. 
without having to resort to sunspot variables to explain how investors coordinate in one equilibrium.

Traditional bank runs were typically the outcome of massive deposit withdrawals by individual depositors. Modern bank runs are typically the outcome of non-renewal of short-term credit in the interbank market, like in the case of Northern Rock or the 2007 run on SIV.

Let us consider a stylized banking crisis model based on Rochet and Vives (2004) and Vives (2010a). The model has three dates: $t=0,1,2$. On date $t=0$, the bank has equity $E$ (or, more in general stable funds) and collects uninsured certificates of deposit (CDs) or short-term uninsured debt in amount $D_{0} \equiv 1$. These funds are used to finance risky investment $I$ and cash reserves $M$. The returns $\theta I$ on these assets are collected on date $t=2$ and if the bank can meet its obligations, the CDs are repaid at their face value $D$, and the equityholders of the bank obtain the residual (if any). A continuum of fund managers makes investment decisions in the interbank market. At $t=1$ each fund manager, after the observation of a (conditionally independent) private signal about the future realization of $\theta$, decides whether to cancel $\left(y_{i}=1\right)$ or renew his $\operatorname{CD}\left(y_{i}=0\right)$. It is assumed that all random variables follow a Gaussian distribution with $\theta \sim N\left(\bar{\theta}, \tau_{\theta}^{-1}\right)$ and the private signal for investor $i$ is $s_{i}=\theta+\varepsilon_{i}$ with i.i.d. distributed noise $\varepsilon_{i} \sim N\left(0, \tau_{\varepsilon}^{-1}\right)$ orthogonal to $\theta$.

Let $\tilde{y}$ be the amount of withdrawals. If $\tilde{y} \geq M$ then the bank has to sell some of its assets to meet payments. A fund manager or investor adopts a behavioral rule of the type: cancel the investment if and only if the probability that the bank fails is above threshold $\gamma \in(0,1)$. This will come about, for example, if the fund manager is rewarded for taking the right decision (that is, withdrawing if and only if the bank fails). 
Let $m \equiv M / D$ be the liquidity ratio; $\theta_{L} \equiv(D-M) / I$, the solvency threshold of the bank; $\lambda>0$ the fire sales premium of early sales of bank assets; and $\theta_{H} \equiv(1+\lambda) \theta_{L}$ the "supersolvency" threshold such that a bank does not fail even if no fund manager renews his CDs. Under these conditions the bank fails if $\theta<\theta_{L}$ or

$$
\tilde{y} \geq m+\frac{1-m}{\lambda}\left(\frac{\theta}{\theta_{L}}-1\right)
$$

For $\theta \geq \theta_{L}$. When taking into account the balance sheet constraint at $t=0$, $E+D_{0}=I+M$ we have that $\theta_{L} \equiv(1-m) /\left(\ell^{-1}+d^{-1}-m\right)$, where $\ell=D / E$ is the shortterm leverage ratio and $d=D / D_{0}$ the return of the short-term debt. An increase in the face value of debt $D$ may be the outcome of the bank facing a more competitive environment.

The model can be reinterpreted replacing bank by country and the short-term debt by foreign-denominated short-term debt.

The game among investors is a symmetric binary action game of strategic complementarities. ${ }^{22}$ If the state of the world is known, then if $\theta<\theta_{L}$ it is a dominant strategy to withdraw; if $\theta>\theta_{H}$ then it is a dominant strategy not to withdraw; and for $\theta \in\left(\theta_{L}, \theta_{H}\right)$ both equilibria coexist. It can be shown that with incomplete information an equilibrium is characterized by two thresholds $\left(s^{*}, \theta^{*}\right)$ with $s^{*}$ yielding the signal threshold below which an investor withdraws and $\theta^{*} \in\left[\theta_{L}, \theta_{H}\right]$ the state-of-the-world critical threshold, below which the acting mass of investors makes the bank fail. There are at most three equilibria. There is a critical liquidity ratio $\bar{m} \in(0,1)$ such that $\theta^{*}=\theta_{L}$ for $m \geq \bar{m}$, and for $m<\bar{m}$ we have that $\theta^{*}>\theta_{L}$ and then the equilibrium is unique if and

22 Related examples can be found in Morris and Shin $(1998,2004)$ ) and Corsetti et al. (2006). In a game of strategic complementarities the marginal return of the action of a player is increasing in the level of the actions of rivals. This leads to best replies being monotone increasing. See Vives (2005). 
only if $\tau_{\theta} \tau_{\varepsilon}^{-1 / 2} \leq \sqrt{2 \pi}\left(\ell^{-1}+d^{-1}-m\right) \lambda^{-1} .{ }^{23}$ The reason is as follows. Let $R(\hat{s})$ be the best reply threshold of a player to the (common) signal threshold $\hat{s}$ used by the other players. The game is, indeed, of strategic complementarities with $R^{\prime} \geq 0$ : a higher threshold $\hat{s}$ by others induces a player to use also a higher threshold. It can be shown that if $\tau_{\theta} \tau_{\varepsilon}^{-1 / 2} \leq \sqrt{2 \pi}\left(\ell^{-1}+d^{-1}-m\right) \lambda^{-1}$ then $R^{\prime}(\hat{s}) \leq 1$. This ensures that $R(\cdot)$ crosses the $45^{\circ}$ line only once and that the equilibrium is unique. In Figure 8 the uniqueness case is illustrated with the flatter reaction curve and the one with multiple equilibria (three) with the steeper reaction curve.

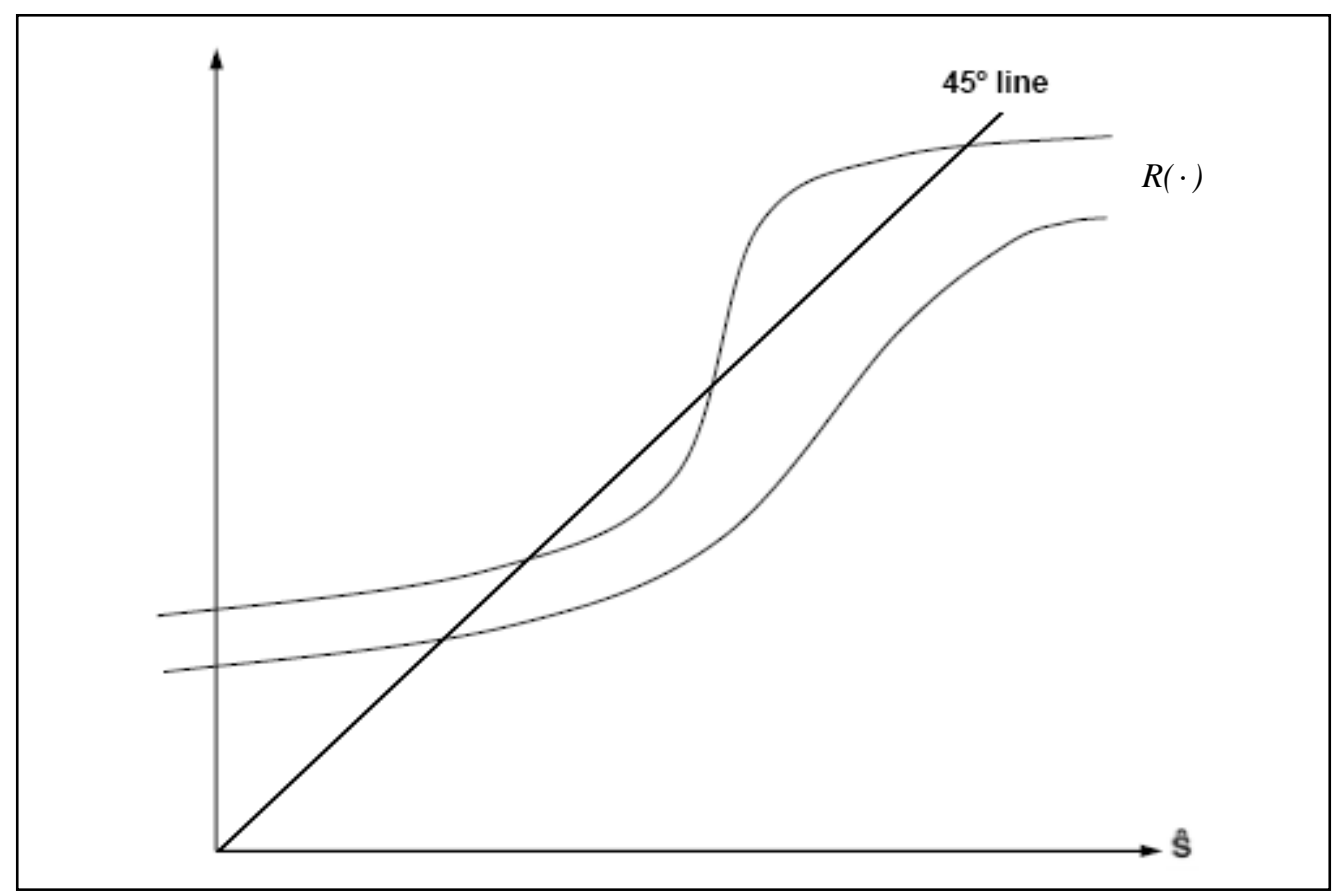

Figure 8: Best response of a player to the threshold strategy $\hat{s}$ used by rivals.

Multiple equilibria come about when strategic complementarity is strong enough (the steeper best response in Figure 8) and this is a function of the slope of the best response. The maximal value of the slope is $\left(\tau_{\theta}+\tau_{\varepsilon}\right) /\left(\tau_{\varepsilon}+\left(\ell^{-1}+d^{-1}-m\right) \lambda^{-1} \sqrt{2 \pi \tau_{\varepsilon}}\right)$. Strategic complementarity will be larger in a more competitive situation ( $d$ larger) and when the fire sales penalty $\lambda$ is higher. It will be smaller with small noise in the signals in relation

23 All the results presented in this section are to be found in Vives (2010). 
to the prior $\left(\tau_{\theta} / \sqrt{\tau_{\varepsilon}}\right)$. With small noise in the signal a player faces greater of uncertainty about the behavior of others and the strategic complementarity is lessened.

At equilibrium with threshold $\theta^{*}$, when $\theta<\theta^{*}$ the acting mass of withdrawing investors make the bank fail and therefore the probability of occurrence of a "crisis" is $\operatorname{Pr}\left(\theta \leq \theta^{*}\right)$. A crisis occurs for low values of the fundamentals. In contrast, in the complete information model there are multiple self-fulfilling equilibria in the range $\left(\theta_{L}, \theta_{H}\right)$. In consequence the model builds a bridge between the self-fulfilling theory of crisis (e.g., Diamond and Dybvig (1983)) and the theory that links crisis to the fundamentals (e.g., Gorton (1985)).

In the range $\left[\theta_{L}, \theta^{*}\right)$ there is coordination failure from the point of view of the institution attacked, the bank is solvent but illiquid, that is, the bank would have no problem if only investors would renew their CDs, but in the range they do not and the bank is illiquid. Correspondingly, the risk of illiquidity is therefore given by $\operatorname{Pr}\left(\theta_{L} \leq \theta<\theta^{*}\right)$ and the risk of insolvency by $\operatorname{Pr}\left(\theta<\theta_{L}\right)=\Phi\left(\sqrt{\tau_{\theta}}\left(\theta_{L}-\bar{\theta}\right)\right)$.

Whenever $m<\bar{m}$ and there is a unique equilibrium and an increase in $d$ or $\lambda$ increases both $\theta^{*}$ and $s^{*}$, the probability of crisis $P\left(\theta<\theta^{*}\right)$, and the range of fundamentals $\left[\theta_{L}, \theta^{*}\right)$ for which there is coordination failure (Vives (2010a)). ${ }^{24}$ An increase in the vulnerability of banks, be it the face value of deposits of bank or level of fire-sales premium for early liquidation, increases fragility by increasing the degree of strategic complementarity. Furthermore, a release of a public signal $\bar{\theta}$ has a (negative) multiplier effect on equilibrium thresholds which is enhanced if $d$ or $\lambda$ are higher. Indeed, the

24 Goldstein and Pauzner (2005) also show how increasing the deposit rate increases the probability of a run of depositors in a model of the global games type. 
equilibrium signal threshold is determined by $R\left(s^{*} ; \bar{\theta}\right)-s^{*}=0$. From which it follows that

$$
\left|\frac{d s^{*}}{d \bar{\theta}}\right|=\frac{|\partial r / \partial \bar{\theta}|}{1-R^{\prime}}>\left|\frac{\partial r}{\partial \bar{\theta}}\right|
$$

whenever the uniqueness condition $R^{\prime}<1$ is met since $R^{\prime}>0$. In consequence, an increase in $\bar{\theta}$ will have a larger effect on the equilibrium threshold $s^{*}$ than the direct impact on the best response of a player $\partial R / \partial \bar{\theta}$. This multiplier effect is largest when $R^{\prime}$ is close to 1 , that is, when strategic complementarities are strong, and we approach the region of multiplicity of equilibria. This is so when $d$ or $\lambda$ are large. Public information has a coordinating potential beyond its strict information content (as emphasized by Morris and Shin (2002)). Every investor knows that an increase in $\bar{\theta}$ will shift downward the best replies of the rest of the investors and everyone will be more cautious in withdrawing.

Consistently with the result, there is experimental evidence that bank runs occur less frequently when banks face less stress in the sense of a larger number of withdrawals being necessary to induce insolvency. ${ }^{25}$

The presence of market power in the interbank market may either facilitate liquidity provision (because liquidity is a public good and then sound banks may have an incentive to provide liquidity to a bank in trouble to avoid contagion (Allen and Gale (2004), Sáez and Shi (2004)) or may impede its provision (as banks with surplus funds underprovide lending strategically to induce fire-sales of bank-specific assets of needy intermediaries (Acharya et al. (2009)).

The comparative statics results hold even if there are multiple equilibria for the extremal (stable) equilibria. It can be shown that extremal equilibrium thresholds $\left(\theta^{*}, s^{*}\right)$ decrease with $\bar{\theta}$ and with decreases in stress indicator $d$ or $\lambda$. Considering out-of-equilibrium

25 See Madies (2006) and Garratt and Keister (2009). 
adjustment in the form of best-reply dynamics where, at any stage after the perturbation from equilibrium, a new state of the world $\theta$ is drawn independently and a player responds to the strategy threshold used by other players at the previous stage, a similar result holds since the middle "unstable" equilibrium becomes irrelevant. Interestingly, the region of multiplicity $\tau_{\theta} \tau_{\varepsilon}^{-1 / 2} \leq \sqrt{2 \pi}\left(\ell^{-1}+d^{-1}-m\right) \lambda^{-1}$ is enlarged with an increase in stress indicator $d$ or $\lambda$ and/or an increase in the precision of the public signal in relation to the private ones $\tau_{\theta} / \sqrt{\tau_{\varepsilon}}$.

Regulation in the form of solvency and/or liquidity requirements may help to control the probabilities of insolvency and illiquidity (Vives (2010a)). Indeed, the probability of insolvency $\operatorname{Pr}\left(\theta<\theta_{L}\right)$ is decreasing in $m=M / D$ (assuming that $1-\ell^{-1}-d^{-1}<0$ as is usual in a commercial bank), the solvency ratio $\ell^{-1}=E / D$, and $d^{-1}$ since $\theta_{L} \equiv(1-m) /\left(\ell^{-1}+d^{-1}-m\right)$. The probability of a crisis $\operatorname{Pr}\left(\theta<\theta^{*}\right)$ (including the probability of illiquidity) is decreasing in $m, \ell^{-1}$ (and also in $d^{-1}$ and $\lambda^{-1}$ ) since $\theta^{*}$ is.

From this it follows that both the solvency and the liquidity requirements needed to control the probabilities of insolvency and illiquidity may have to become tighter in a more competitive environment where $d$ is higher. Furthermore, the liquidity requirement may have to become tighter in a crisis situation where $\lambda$ is higher. ${ }^{26}$ However, account must be made that there is a partial substitutability between $m$ and $\ell^{-1}$ since they both contribute to decrease $\theta_{L}$ and $\theta^{*}$. In the limit case of almost perfect signals, $\tau_{\varepsilon} \rightarrow \infty$, which allows for a closed-form solution, it can be checked that in a more competitive environment (with higher return on short-term debt $d$ ) the solvency requirement has to be strengthened (but not the liquidity ratio), while in a crisis situation (where the fire sales penalty $\lambda$ increases) the liquidity requirement has to be strengthened while the solvency one relaxed.

26 See Vives (2009). 
Consistently with the results presented there is evidence that banks with relied less on wholesale funding, and had higher capital cushions and liquidity ratios, fared better during the crisis. ${ }^{27}$

In summary, runs can happen independently of the level of competition but more competitive pressure worsens the coordination problem of investors/depositors and increases:

(i) Potential instability (enlarging the multiplicity of equilibria region).

(ii) The probability of a crisis.

(iii) The range of fundamentals for which there is coordination failure of investors (and the institution is solvent but illiquid).

(iv) The impact of bad news on fundamentals.

(v) The solvency requirement.

It is worth pointing out that the socially optimal probability of a crisis is positive in general because of its disciplining effect. Therefore the preceding results do not imply that competitive pressure has to be minimized.

\subsection{Competition and risk taking}

Banks will have excessive incentives to take risk in the presence of limited liability (for shareholders and managers) and moral hazard (non-observable risk on asset side). This is exacerbated by flat deposit insurance and the problem is particularly acute for banks close to insolvency/bankruptcy. Indeed, limited liability will imply that banks will take excessive risk on the asset side except if the risk position of the bank can be assessed (for example, by large holders of CDs). A bank then cannot increase its market share and profits by taking more risk because investors discount it. However, introducing flat premium deposit insurance (or bailouts) destroys the disciplining effect of the market because then investors do not care about the failure of the bank.

27 See Ratnovski and Huang (2009) with evidence from the 72 largest commercial banks in OECD countries. 
Intense competition may worsen the excessive risk taking problem because high profits provide a buffer and increase the "charter value” of the bank. In a dynamic setting market power enhances the charter value of a bank and makes the bank more conservative. Indeed, a bank with more market power enjoys higher profits and has more to lose if it takes more risk, fails and its charter is revoked and if future profits weigh enough the bank will moderate its risk taking. Besanko and Thakor (1993) make this point with the value created with relationship banking, and Boot and Greenbaum (1993) with reputational benefits, both eroded with more competition. ${ }^{28}$ Matutes and Vives (2000) consider an imperfect competition model where banks are differentiated, have limited liability and there are social costs of failure (which could include a systemic component). The authors show that deposit rates are too high when competition is intense and the social cost of failure high. If the risk assumed by the investments of the bank is not observable then the incentives to take risk are maximal. Flat premium deposit insurance tends to make the banks more aggressive by increasing the elasticity of the residual supply of deposits faced by the bank (this is also the result in Matutes and Vives (1996)). Furthermore, with risk-insensitive insurance deposit rates will be too high with intense competition even with no social cost of failure and there is no discipline on the asset risk taken. Allen and Gale (2004) consider banks competing à la Cournot in the deposit market and choose a risk level on the asset side. With insured depositors they show that as the number of banks grows banks have maximal incentives to take risk on the asset side. ${ }^{29}$

With heterogeneous borrowers tougher competition may lead to a more risky portfolio’s of banks and higher failure probabilities. This is so because more rivalry may reduce incentives to screen borrowers (the bank has less informational rents, Allen and Gale (2004)). A larger number of banks may increase also the chance that bad borrowers get

28 A better reputation lowers the cost of outside finance to the bank.

29 See also Hellman et al. (2000), and Cordella and Yeyati (2002). 
credit by reducing the screening ability of each bank due to adverse selection/winner's curse problem (Broecker (1990), Riordan (1993), Gehrig (1998)). ${ }^{30}$

However, competition tends to lower the rates that firms have to pay for loans and therefore may improve the average quality of loan applicants and/or lower the need to ration credit. For example, better terms for entrepreneurs means that they make more profits and become more cautious, affecting in turn the probability of failure of the bank (Caminal and Matutes (2002); Boyd and De Nicolò (2005)). Martinez-Miera and Repullo (2008) show that this argument does not take into account that lower rates also reduce the banks' revenues from non-defaulting loans. When this is accounted for, there is a Ushaped relationship between competition and the risk of bank failure (in particular, when the number of banks is sufficiently large, the risk-shifting effect is always dominated by the margin effect). In summary, when both banks and firms have to monitor their investments there is a potential ambiguous relationship between market structure and risk taking.

A bank faces both adverse selection and moral hazard problems when lending to firms. A higher rate set by the bank will tend to draw riskier applicants (adverse selection) and/or induce the borrower firms, which have also limited liability, to choose riskier projects (moral hazard). We know that banks may find optimal then to ration credit instead of raising the interest rate. A bank with market power has more incentive to alleviate this asymmetric information problem by investing in monitoring the projects of firms and establishing long term relations with customers. ${ }^{31}$ This effect tends to increase the availability of credit to firms. Market power has also the usual effect of increasing the lending rate and therefore increasing the tendency towards credit rationing to avoid the increase of the average risk in the pool of applicants. Even abstracting from the possibility of banking failure market power presents a welfare trade-off since more bank market clout diminishes the moral hazard problem faced by the bank but aggravates the

30 It should be taken into account also that endogenous fixed costs due to information gathered via lending may induce a natural oligopoly in banking (Dell'Ariccia et al. (1999), Dell'Ariccia (2001)).

31 Besanko and Thakor (1993), Petersen and Rajan (1994, 1995). 
problem for the entrepreneur. The result is that some market power tends to be good unless monitoring is very costly. If banking failure is a possibility then the analysis becomes more complex. Higher lending rates due to market power tend to depress investment and, under plausible assumptions with multiplicative uncertainty, to decrease the overall portfolio risk of the bank. More rivalry should increase then the probability of failure of the bank. However, more competition may destroy also incentives to monitor and therefore reduce lending. If the latter effect is strong enough a monopolistic bank may be more exposed to aggregate uncertainty (because it tends to ration credit less) and be more likely to fail. ${ }^{32}$

All in all, despite the complexity of the relationship between competition and risk taking it seems plausible to expect that, once a certain threshold is reached, an increase in the level of competition will tend to increase risk taking incentives and the probability of failure of banks. This tendency may be checked by reputational concerns, by the presence of private costs of failure of managers, or by appropriate regulation and supervision.

\section{Evidence}

Increased competition after liberalization and deregulation in the US in the 1980s led to increased risk taking by banks (Keeley (1990), Edwards and Mishkin (1995), Demsetz et al. (1996), Galloway et al. (1997)). Keeley finds that a higher Tobin's $q$ (as a measure of charter value) is positively associated with high capital-to-asset ratios in US bank holding companies in the period 1971-1986. Furthermore, he finds that interest rates of large CDs for large banking holding companies between 1984 and 1986 are negatively related to $q$. It seems also that the increase in risk held in particular by large banks which were TBTF (Boyd and Gertler (1993)). However, there is controversy over whether this increase in competition led to lower or higher loan losses (see Jayaratne and Strahan (1998) and Dick (2007), respectively). Saurina et al. (2007) claim that non performing loans in Spanish

32 Caminal and Matutes (2002). 
banks decrease with increases in the Lerner index in the loan market. ${ }^{33}$ Salas and Saurina (2003) find that liberalization measures in Spain over 31 years have increased competition and eroded banks' market power (measured again by Tobin's $q$ ), banks with lower charter values tend to have lower equity-assets ratios (lower solvency) and to experience higher credit risk (loan losses over total loans).

Liberalization in a weak institutional environment and/or with inadequate regulation leads to risk-shifting to the taxpayer and systemic crisis (Demirgüç-Kunt and Detragiache (1998, 2001)). A similar situation seems to have happened in the wake of the subprime crisis with declining lending standards associated to securitization (Dell'Ariccia et al. (2008)).

The relations between concentration and stability are complex. On the one hand, a concentrated banking system with a few large banks may be easier to monitor and banks are potentially better diversified. But on the other hand large banks may be TBTF, receive larger subsidies, and have incentive to take more risk. Furthermore, large banks tend to be more complex and harder to monitor as well as more interdependent (leading to more systemic risk). The evidence also points to a complex relationship between concentration and stability.

Several studies have attempted to provide cross-country evidence on the effects of liberalization and increase in competition on both individual and systemic bank failures. Berger et al. (2009) in a cross-country study of 23 developed nations show that market power (as measured by the Lerner index or the HHI on deposits/loans at national level) increases loan portfolio risk of banks but decreases overall risk because banks with market power hold more equity capital. Beck et al. (2006) in a cross-country study of 69 nations (1980-1997) show that systemic crises are less likely in concentrated banking systems (measured by the three-firm concentration ratio on total assets, controlling for macro, financial, regulatory, institutional and cultural characteristics) and that fewer

33 However, a problem with their approach is that the risk premium in the Lerner index is a function of loan losses ratio which is a measure of nonperforming loans. 
regulatory restrictions (on entry, activities, facility for competition) are associated with less systemic fragility. This would seem to indicate that concentration does not proxy for competition and puts into question that market power is stabilizing. However, the relevant connection is between concentration in relevant markets (which need not be directly linked with aggregate asset concentration) and competition. Furthermore, concentration is, in fact, endogenous and more competition may increase concentration in a free entry world (as there is less room for entrants). ${ }^{34}$ In this sense to find both concentration and competition positively associated to stability should not be surprising. Concentrated systems tend to have larger and better-diversified banks (controlling for the size of the domestic economy eliminates the relationship between concentration and crises) but no connection is found with the ease of monitoring banks. The message of Beck et al. (2006) seems to be: "More competitive banking systems are associated with less fragility when controlling for concentration”. A similar conclusion is reached by Schaek et al. (2009) using the Panzar-Rosse H-statistic to proxy for competition with data for the period 1980-2005 and 45 countries. Those authors, however, find that concentration itself is associated with a higher probability of a crisis.

Boyd, De Nicolò, and Loukoianova (2009) in a cross-country study with individual bank data use a model-based definition of stress or crisis and find that more concentration leads to a higher probability of a systemic shock but not a larger probability of government intervention. The authors claim that indicators of banking crises in the literature are in fact indicators of the government response to the crisis (and that those are predicted by base indicators such as sharp reductions in profits, loans and deposits). According to the authors the interpretation of the results in Beck et al. (2006) would be that more concentration leads to less intervention (more forbearance by regulators) and more systemic crises, and that less barriers to entry lead to less intervention and less crises. Boyd, De Nicolò and Jalal (2009) in a cross-country study with individual bank data (in emerging economies and US banks) find also that more concentration leads to increased probability of failure of banks and that bank competition fosters willingness to lend. Shehzad and De Haan (2009) with cross-country data (1973-2002) find that certain

34 See Vives (2000). 
dimensions of liberalization reduce the likelihood of systemic crises conditional on adequate banking supervision.

Diversification can be achieved with mergers between financial institutions but large banks need not be better diversified. Empirical studies in the US find strong benefits of consolidation (improving profitability and production efficiency, and reducing insolvency risk) when the degree of macroeconomic (geographic) diversification increases (Hughes et al $(1996,1998)){ }^{35}$ More precisely, those authors find that geographic diversification offsets the tendency of larger banks to take more insolvency risk (controlling for diversification). An expansion in asset size is associated with a less than proportionate increase in expected profit and a more than proportionate increase in risk. An expansion in asset size and the number of branches within the same state is associated with a more than proportionate increase in expected profit and a less than proportionate increase in risk. An expansion in asset size, branches and diversification across states is associated with an improvement in value efficiency and reduction of insolvency risk. Consolidation within the state reduces insolvency risk but does not improve market value. It has also been claimed that increased consolidation has led to increased systemic risk in the US by looking at the positive trend of stock returns correlations for large and complex banking organizations in the period 1988-1999 (De Nicolò and Kwast (2002)).

Internationalization is a way to achieve diversification. Furthermore, allowing multinational banks into previously protected markets may increase the range of financial services offered in the domestic market and lower margins. A side effect may be the erosion in the charter value of domestic banks inducing them to take on more risk. Both cross-border banking and foreign bank entry have been seen to improve financial intermediation, foster growth and reduce fragility (see Claessens (2006) and Barth et al. (2004)). The effects have happened both directly and indirectly with competitive reactions of domestic banks. However, some evidence points also at mixed distributional effects of foreign bank entry. Detragiache et al. (2008) find that foreign bank entry in

35 See also Demsetz and Strahan (1997). 
poor countries may lower private credit growth. Berger et al. (2001) find that large foreign-owned institutions concentrate on large-scale projects and may leave aside small firms. Still, large well-capitalized foreign banks may have also an influence providing stability to the domestic financial system of an emerging economy. However, while the headquarters of foreign banks would provide help to a subsidiary when a problem develops (because the brand name and the franchise value of the bank are at stake), this need not hold when a systemic problem develops (as an example take the case of the collapse of the currency board in Argentina). ${ }^{36}$ Furthermore, even if foreign bank headquarters were willing to help, they need not do so at the optimal social level, since they will not take into account the external effects of their help. For example, the headquarters of foreign banks may want to limit their exposure to a country that may face a currency crisis and therefore will tighten liquidity provision to branches or subsidiaries in the country. Finally, the incentives of a foreign lender of last resort and supervisor need not be in line with local interests. A foreign supervisor will not take into account the consequences (systemic or not) for domestic residents of a restructuring of a local branch or subsidiary but only the consequences for systemic stability at home of a crisis of a subsidiary abroad. ${ }^{37}$

Finally, there is ample evidence that institutions close to insolvency have incentives to gamble for resurrection (e.g. S\&Ls crisis).

It is worth noting that the financial crisis seems to have affected banks in countries with different concentration levels and market structures. Although it has been pointed out, for example, that concentrated banking systems like in Australia and Canada have fared better in the crisis than unconcentrated ones like in the US or Germany there have also been problems in concentrated countries like the Netherlands or the UK (for retail banking). Furthermore, other factors are at play, in Canada (and to a lesser extent both Australia) banks get their funds mostly from deposits and not in the wholesale market and

36 Headquarters have to back the deposits in a branch, but need not do it for a subsidiary.

37 See Vives (2006) for further discussion. 
in both countries are subject to strict regulatory requirements. Reliance on non-interest income has also proved to be a source of increased risk and vulnerability. ${ }^{38}$ By the same token it is not evident that certain types of institutions have been more vulnerable than others. Both specialized investment banks (in fact, all the US ones have collapsed or converted to commercial banks), insurance companies like AIG, and universal banks (like UBS, Citigroup, or German and UK banks) have suffered.

In conclusion, the evidence points to the following:

(i) Liberalization increases the occurrence of banking crises while a strong institutional environment and adequate regulation mitigate them.

(ii) There is a positive association between some measures of bank competition (e.g. low entry barriers, openness to foreign entry) and stability.

(iii) The association of concentration and stability presents mixed results.

(iv) Larger banks tend to be better diversified but may take also more risk.

\section{Can we regulate away the competition-stability trade-off?}

We have seen how limited liability will imply that banks will take excessive risk on the asset side except if the risk position is observable and market discipline works. Disclosure requirements may help making the risk position of the bank known (or more realistically, better assessed). This is represented by the top row in Table 1. If the asset risk position of the bank is not observable then incentives to take risk are much increased (second row of Table 1) and become maximal when risk-insensitive insurance is introduced since then monitoring incentives are destroyed (third row in Table 1). Riskbased deposit insurance moderates risk taking incentives and undo the limited liability charter of the bank but still banks may take too much risk in the presence of a large social cost of failure which they do not internalize (bottom row in Table 1). In the top and bottom rows an instrument like capital requirements may be sufficient to check risk

38 See Baele et al. (2007), De Jonghe (2010), Demigüç-Kunt and Huizinga (2010), and Ratnosvski and Huang (2009). 
taking but in the middle rows we need to complement capital requirements with asset restrictions. $^{39}$

The general trend in banking regulation has been to check risk taking with capital requirements and appropriate supervision. Both risk-based (deposit) insurance and disclosure requirements have been proposed to limit risk-taking behavior. Advanced economies have tried to move towards the top and the bottom rows of Table 1 . This movement was accompanied by a reform of the 1988 Basel Accord on capital requirements to adjust them better for risk (Basel II). Capital requirements together with supervision and market discipline are the three pillars on which Basel II regulatory reform is based. ${ }^{40}$ Transparency has its limitations, however. While it is feasible to introduce disclosure requirements of the market positions of banks, it is more difficult to assess the risk level of the illiquid loan portfolio of a bank. Furthermore, more disclosure may in fact induce information-based runs of investors generating instability.

\begin{tabular}{|c|c|c|c|}
\hline \multirow[b]{2}{*}{ Banking regimes } & \multicolumn{2}{|c|}{ Risk-taking incentives } & \multirow[b]{2}{*}{ Regulation } \\
\hline & $\begin{array}{l}\text { Liability } \\
\text { (rates) }\end{array}$ & $\begin{array}{l}\text { Asset } \\
\text { (investment) }\end{array}$ & \\
\hline $\begin{array}{l}\text { Free banking } \\
\text { (observable risk/high } \\
\text { disclosure) }\end{array}$ & Medium-low & Absent & Capital requirements \\
\hline $\begin{array}{l}\text { Free banking (unobservable } \\
\text { risk/low disclosure) }\end{array}$ & Medium-high & Maximal & $\begin{array}{l}\text { Capital requirements and asset } \\
\text { restrictions }\end{array}$ \\
\hline Risk-insensitive insurance & High & Maximal & $\begin{array}{l}\text { Capital requirements and asset } \\
\text { restrictions }\end{array}$ \\
\hline Risk-based insurance & Low & Absent & Capital requirements \\
\hline
\end{tabular}

Table 1. Possible banking regimes, the incentives to take risk on the liability and asset sides, and the necessary regulatory instruments when charter values have low values and the social cost of failure is high.

39 See Matutes and Vives (2000), Hellmann et al. (2000), and Repullo (2004).

40 According to Basel II's guidelines on capital requirements that banks can either adopt a "standardized" approach in which external rating agencies will be used to set the risk weight for the different types of loans (say corporate, banks, and sovereign claims) or an internal-rating-based approach in which banks estimate the probability of default and also the loss given default in an advanced version of the method. The idea is to calibrate the capital requirement so that it covers the Value at Risk (expected and unexpected) from the loan under some assumptions. 
The present crisis is a testimony of the failure of the strategy to move towards the top and bottom rows of the table. Disclosure and risk assessment have been deficient (among other things because of the failure of rating agencies), and market discipline has been ineffective because of the blanket insurance offered by TBTF policies. Furthermore, capital regulation has not taken into account systemic effects (the social cost of failure) and assets restrictions have been lifted under the pressure of investment bank lobbies. ${ }^{41}$

We are stuck in the "risk-insensitive insurance" row with maximal risk taking incentives. We need therefore to design appropriate capital requirements and asset restrictions. Optimal regulation would need a combination of risk-based insurance for deposits (which implies that insurance premiums are contingent on the rates offered by banks as well as their asset risk position and eliminates, or compensates exactly, limited liability) and systemic capital charges that internalize the social cost of failure of banks. If the asset risk position of banks is not observable then insurance can not be contingent on it and banks will be induced to take maximal risk on the asset side. This will have to be checked with asset restrictions (e.g., separation of banking and proprietary trading/investment banking activities). Furthermore, the appropriate level of the systemic capital charge will depend in general (in an increasing way) on the intensity of competition, and will be binding in a low-medium friction environment.

According to the analysis in Matutes and Vives (2000) the level of capital requirement will be an increasing function of both the social cost of failure $K$ and the intensity of competition (inverse friction) in the market ( $\lambda$, which in the model goes from maximal differentiation $\lambda=0$ to no differentiation $\lambda=1$ ). This is so since typically the level of friction is not only a behavioral parameter but a parameter that enters the utility function. ${ }^{42}$ In this case a capital requirement should be set as a function of the level of $\lambda$.

41 Financial regulation is known to be subject to strong lobby pressure. For example, Kroszner and Strahan (1999) document it in the process of abandonment of branching restrictions in the US.

42 For example, differentiation - a source of friction and market power- is valued by customers. Then an increase in differentiation will imply that banking customers value more the volume offered by the bank and therefore a more lenient capital requirement is appropriate. 
This result is consistent with the analysis in section 4.1 where the solvency requirement has to be tightened in a more competitive environment.

Figure 9 depicts the regions in the space of intensity of competition $\lambda$ (with $\lambda=0$ for an independent monopolies situation and $\lambda=1$ for perfect competition) and social cost of failure $K$ for which it is optimal to disintermediate (“optimal disintermediation”), and for which deposit rates are too high $\left(r^{\prime}>r^{o}\right)$ or too low $\left(r^{\prime}<r^{o}\right)$ from the welfare point of view. For a give level of competition $\lambda$ if $K$ is very large it is optimal to disintermediate, if $K$ is intermediate then banks are too aggressive and take too much risk on the liability side and a binding capital charge (as a function of $\lambda$ ) has to be imposed, and if $K$ is low then banks are not aggressive enough, the capital charge will not be binding and an increase in competitive pressure would be welfare-enhancing. Competition policy pressure is needed in a high friction environment.

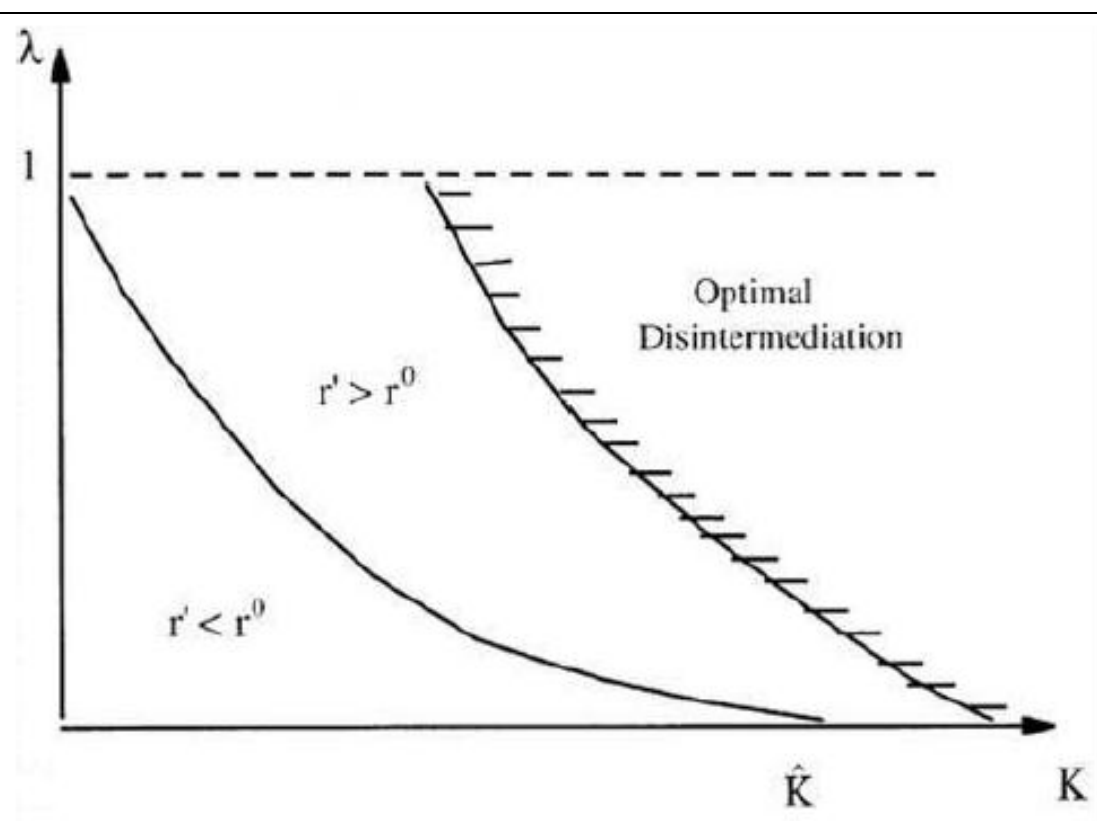

Source: Figure 3 in Matutes and Vives (2000).

Figure 9: Comparison of market and optimal deposit rates as a function of the friction in the market $(1 / \lambda)$ and social cost of failure $K$. 
With precise knowledge of $K$ and $1 / \lambda$ the competition-stability trade-off can be regulated away. Just, set up the appropriate capital charge and let banks compete (with the usual enforcement of competition policy).

The competition-stability tradeoff also applies to emerging economies. An emerging market economy is characterized by high uncertainty, increased likelihood and incidence of financial and currency crises, predominant financial role of banks, and weak supervisory structure. These characteristics make it much more difficult to follow the developed country regulatory strategy in an emerging market economy. First, it is more difficult to move toward a disclosure strategy because information problems are more acute and the production of information costlier. Second, risk-based deposit insurance can work only when insurance can be priced according to objective indicators of bank risk, which will be more difficult to obtain in an emerging market economy (and we know they are difficult to obtain even in a developed economy). This makes the move toward a risk-based insurance strategy more difficult (as the potentially problematic application of Basel II shows). It follows that regulation of banking and financial markets must be adapted for emerging market economies. Those economies will tend to have a higher cost of liquidation of projects and social cost of failure, as well as a higher level of friction. The first two factors will push towards a tightening of the regulation while the higher friction may pull in the opposite direction.

In conclusion, the trade-off between competition and stability is complex but seems real (at least along some dimensions). Well-designed regulation may alleviate the trade-off but needs to take it into account. This means in particular that capital requirements with allowance for systemic externalities need to adjust for the level of friction in the market, becoming tighter when competition is more intense. In a world where fine-tuning of regulation is difficult (and the experience with banking regulation so far seems to indicate that this is the case) it does not seem prudent to strive for the complete elimination of market power in banking. This may have implications in terms of an optimal degree of concentration, which is likely to be intermediate. In emerging economies, optimal policy needs to carefully balance the impact of the different levels of friction and social cost of 
failure. In any case, what is clear is that competition should be limited for institutions close to insolvency. This should be done in a prompt corrective action frame where the supervisor has to intervene as red flags of depleting capital are raised. ${ }^{43}$

\section{The policy response to a financial crisis ${ }^{44}$}

\subsection{Interventions and distortions}

In a systemic crisis situation there is tremendous pressure to stabilize the system. In the 2007-2008 crisis we have witnessed an array of interventions: asset purchase and guarantee schemes (including extensions of deposit insurance, and guarantees in the interbank market and in mutual funds), capital injections, outright nationalization, and forced mergers. These interventions represent a large distortionary potential in terms of moral hazard, long term effects in market structure, protection of inefficient incumbents and creation of an uneven playing field (among different institutions and different countries). For example, helped institutions which have proved to be TBTF may end up with a lower cost of capital than others (not only in the short term but also in the longterm because of the implicit guarantee they obtain). The result is that, ex-ante, the incentives are to take excessive risk. This is compounded with subsidy races to help national champions and marketplaces. This effect is particularly apparent in the EU posing a threat to the single market. The help provided to the system may foster regulatory forbearance to cover losses. There is indeed evidence that regulatory forbearance is prevalent and the government is less likely to close or take over failing bank when the banking sector is weak: the cases of S\&Ls in the US, Japan's banking crisis, and according to the evidence on 21 emerging countries of Brown and Dinç (2009)). Finally, help to banks has spillovers to other sectors that demand more help (like

43 In fact, according to the US Federal Deposit Insurance Corporation Improvement Act (FDICIA) of 1991 when a bank solvency level is below a certain limit it cannot expand its assets. Larger decreases in solvency may trigger the need to recapitalize or even the imposition of rate ceilings. The idea of the FDICIA is to reduce the discretion of the regulator with rigid intervention rules which are gradual. (See, e.g., Dewatripont and Tirole (1994).)

44 This section is based on Vives (2010b). 
automobiles, for example).

The crisis has forced mergers of institutions backed by government subsidies and/or guarantees. ${ }^{45}$ The upshot is that surviving incumbents increase market power and have a lower cost of capital because they are TBTF (and/or because of the public help). Here it must be recalled that merger policy affects degree of competition and dynamic incentives. The takeover of a failed bank may reward an incumbent with temporary monopoly rents, inducing monopoly inefficiency but prudent behavior. This is optimal only if subsequent entry is facilitated (Perotti and Suarez (2002)). The danger now is that incumbents increase their market power and are protected from entry. A merger policy must have a long horizon, and even in a crisis situation, must consider the optimal degree of concentration in the industry, dynamic incentives for prudence of incumbents and the ease of entry.

State intervention and even outright ownership have been necessary to stabilize the system. Indeed, when the taxpayer is footing the bill the public sector must have a say in the running of the helped institutions. However, government ownership is distortionary: government is on both sides of the regulatory relationship; political objectives/and incentives rule ${ }^{46}$; if not disciplined by competition it induces less competitiveness of the banking system, inefficiency, and less financial stability with higher risk exposure and more bank losses (Barth, Caprio, and Levine (2004), Caprio and Martinez Peria (2002), De Nicolò and Loukoianova (2007)); it eliminates the market for corporate control; creates an uneven playing field (with implicit and explicit guarantees); and ends up inducing less competition and lower financial development.

45 In the US, Bear Sterns merged in March 2008 with JP Morgan backed-up by the Federal Reserve, JP Morgan later in the year acquired banking assets of Washington Mutual from the FDIC, and Merrill Lynch merged with Bank of America (going over, together with Wells Fargo acquiring Wachovia in 2008, the 10\% national market share deposit threshold established by the Riegle-Neal Act (1994)). In the UK, the merger of HBOs and Lloyds TBS was approved against the OFT's opinion (with partial nationalization) despite a $30 \%$ market share of the merged entity in current accounts/mortgages and competition problems in SME banking services in Scotland. It is worth noting that Lloyds was not allowed to take over Abbey in 2001.

46 The evidence presented by Hau and Thum (2009) on board incompetence in German public banks (there is a wide difference in terms of education, financial and management experience in the 29 largest German banks between private and public) is suggestive, linking larger losses borne in the crisis linked to the lack of professionalism in boards. 
Policy intervention in a crisis has to walk a narrow path between the support measures to avoid contagion and protect financial stability, and the desire to maintain a vigorous longterm competition. Unavoidably some trade-off between the two objectives, particularly in the short-term, will exist. When a systemic crisis strikes there is little time to react and support measures have to be implemented very quickly. Central banks, regulators and fiscal authorities provide the support measures and the competition authority has to watch for distortions on competition (including the formation of market structures nonconducive to competition).

Help to a bank typically provides a positive externality to other banks since it limits the spread of the crisis and protects the system mostly by avoiding contagion, be it informational or because of interbank exposures. This does not distort competition if it is liquidity help that allows a fundamentally sound bank to avoid contagion and ride the crisis. If the bank is in distress but has a solvency problem then this indicates that it should be restructured and help needs to come with strings attached so that competition is not distorted with "bad” banks displacing "good" ones in the business of customers. The counterfactual for whether help is distortionary has to take into account what would have happened if there had not been coordination failure of investors from the point of view of the distressed institution. That is, extracting the panic component in market behavior. This is not an easy task, particularly when compounded by regulatory failures which induce excessive risk taking.

The main tools of intervention to limit distortions are structural (asset divestitures) and behavioral (pricing, advertising, acquisitions) restrictions. Structural commitments may help reduce the post-crisis over-capacity in the banking sector accumulated during the asset boom in many countries. Indeed, an added component in the present crisis is the extent of overcapacity in the banking system. The period of expansion with low interest rates has led to overexpansion of banking via credit particularly in those countries where there has been a real state bubble (e.g. US, Ireland, UK, Spain). This means that branches and personnel are to be cut together with the balance sheet of institutions even if credit is 
normalized (because it should stabilize below the pre-crisis bubble levels). In general, care must be taken so that the commitments, either structural or behavioral, leave the restructured bank as a viable competitor. This is obvious if the bank is a fundamentally sound one. If it is not then restructuring should prevent the bank from taking over business from healthy rivals which have not enjoyed help. In any case, the restructured bank has to be a viable competitor. An important point to check moral hazard is the removal of the management of the helped institution that has behaved imprudently. In this case the behavioral restrictions on the helped bank could be relaxed.

\subsection{The approach in the US and in the EU}

The role of the competition authority has been different in the US and in the EU. The reason is that the EU competition authority has the unique capability, among competition authorities, to control state aid. Since the crisis the EU has dealt with many banking aid cases (taking 22 decisions only in 2008 and 81 decisions as of December 17, 2009). Most of the cases (75) were approved without objection. ${ }^{47}$ The EU has stated conditions for state guarantees/recapitalization (EU Communications October-December 2008) which have been formalized into temporary guidelines on restructuring aid to banks. The conditions imposed on helped institutions are mostly sensible since they try to minimize the distortions introduced by public help, in particular for non-fundamentally sound institutions. ${ }^{48}$ The European Commission has been tough imposing or influencing some important balance sheet reductions and behavioral restrictions on helped entities such as ING, Northern Rock, RBS, Commerzbank or WesLandesbank. Interestingly, in the case of RBS, which has been ordered to sell some retail operations, insurance, and commodity-trading business, the Commission mentions concentration concerns with RBS being the leader in retail and corporate banking for small and medium-sized enterprises

4766 more cases have been cleared under a temporary framework to support lending to firms. DG Competition (December 17, 2009), State aid: overview of national measures adopted as a response to the financial /economic crisis.

48 There is a potential exception in the behavioral requirement which implies a commitment to expand lending. This is contradictory with the restrictive behavior that wants to be imposed on helped institutions and may induce bad practices since the business of a private bank is to lend and what has to be attacked are the causes why the bank is not lending. 
segments, while it mentions also the benefits of the divestments in terms of limiting moral hazard for insurance and commodity-trading business. ${ }^{49}$

Some of the measures can be understood in order to minimize competitive distortions of the aid, others in terms of checking moral hazard in the future. In principle, the role of the competition authority is to preserve competition and not to limit moral hazard, which is the role of the regulator. The important point is that the measures purely aimed at competitive distortions will have an impact also on ex ante incentives (and moral hazard) since a bank will know that help in case of trouble will come with restrictions. This has a connection with the TBTF issue. More broadly, the concept of competitive distortion may encompass competition based on an advantage of being under the TBTF umbrella. In this sense the restrictions on lines of activity which fall outside the regulated core banking business may make sense although they go beyond the standard competition concern and analysis. The RBS case points at the need of coordination between the competition authority and the regulator.

The activism of the EU Commission poses the question of (future) competitive balance with aided US banks for which no divestitures have been required. This may prove important in particular in the segments of the banking business in which there is global competition. The Obama administration, under the advice of Paul Volcker, is advocating limits on size and scope (mostly on proprietary trading) of banks to avoid the "too big to fail” (TBTF) problem as well as controlling risk taking. ${ }^{50}$ What the European Commission is trying to accomplish with state aid control the US may accomplish by regulation. The important side benefit of state aid control in the EU is that it limits the incentives of bankers to take excessive risk in the expectation of a bailout if things go wrong. That is, it addresses the TBTF issue. The competition authority may internalize that if when an institution fails it gets help, competition will be distorted. To limit the size

49 See DG Competition (December 14, 2009), State aid: Commission approves impaired asset relief measure and restructuring plan of RBS.

50 See http://www.whitehouse.gov/the-press-office/president-obama-calls-new-restrictions-size-andscope-financial-institutions-rein-e. 
(or better the systemically-corrected size) of an institution with break ups once they receive public help (something that the EU seems to be implementing) is an option which extends the realm of competition policy. However, the competition authority when ordering divestitures need not take into account systemic considerations. The US so far seems to be following another route where TBTF is explicitly not an antitrust problem (see White (2009)).

In any case, size and scope restrictions are a blunt instrument to deal with the TBTF issue. Controls on size are problematic because interconnectedness and line of business specialization are more important than size for systemic risk. With regard to the scope of the banking firm, conflict of interest is what leads to potential market failure and is the lead to indicate possible scope limitations. Higher capital and insurance charges for systemically important institutions together with effective resolution procedures may be a better way of dealing with the problem. This should be coupled with a serious consideration of conflicts of interest in financial conglomerates. The upshot is that the competition authority in its role of protecting competition may have a say in the TBTF issue and therefore its actions should be coordinated with the regulator. The potential for competition policy to provide a commitment device to partially address TBTF issues should not be dismissed.

The Obama administration move is reminiscent of the XIX century antitrust tradition of looking with suspicion large firms because of the excessive power concentration they entail. Later on antitrust evolved with size not being an offense but market power in a particular market. The influence that investment banks have had in the deregulation of financial intermediaries and the ensuing enormous increase in leverage leading to the crisis is backfiring. We are in the territory of political economy and the question is how to better control excessive concentrations of power in a democratic society. 


\section{Summary and concluding remarks}

Liberalization has gone together with an increase in the competition faced by financial intermediaries and with an increase in the incidence of crises. Bank assets have not declined in relation to total financial assets and banking has transformed itself towards services provision. This restructuring has tended to increase aggregate concentration (although the consequences of this may have been different in relevant retail local markets in the US and Europe). The crisis points to a return to traditional banking and may tend to exacerbate the consolidation trend.

Banks are unique because of their particular mix of features which makes them vulnerable to runs with potentially systemic impact and very important negative externalities for the economy. The fragility of a competitive banking system is typically excessive and financial regulation comes to the rescue at the cost of side effects and regulatory failure. The most important one is the potential moral hazard induced by protection and bail outs extended to failing institutions. The present crisis is a testimony of the failure of the three pillars of the Basel II system. Disclosure and risk assessment have been deficient (think of the failure of rating agencies), and market discipline has been ineffective because of the blanket insurance offered by TBTF policies. Capital regulation has not taken into account systemic effects (the social cost of failure) and assets restrictions have been lifted under the pressure of investment bank lobbies. Supervision has proved ineffective since it has allowed a shadow banking system to grow unchecked.

Theory and empirics point to the existence of a trade-off between competition and stability along some dimensions. Indeed, runs happen independently of the level of competition but more competitive pressure worsens the coordination problem of investors/depositors and increases potential instability, the probability of a crisis and the impact of bad news on fundamentals. This does not imply that competitive pressure has to be minimized since the socially optimal probability of a crisis is positive in general because of its disciplining effect. On the asset side, once a certain threshold is reached, an increase in the level of competition will tend to increase risk taking incentives and the 
probability of failure of banks. This tendency may be checked by appropriate regulation and supervision. The evidence points to liberalization increasing the occurrence of banking crises while a strong institutional environment and adequate regulation mitigating them. At the same time, there is a positive association between some measures of bank competition (e.g. low entry barriers, openness to foreign entry) and stability.

Regulation can alleviate the competition-stability trade-off but the design of optimal regulation has to take into account the intensity of competition. For example, capital charges should account for the degree of friction and rivalry in the environment of the banks, with tighter requirements in more competitive situations. Given that fine-tuning of regulation has proved very difficult in practice (this is probably an understatement given the massive regulatory failure that the crisis has uncovered), the trade-off between competition and stability is bound to persist and the coordination of regulation and competition policy in banking seems necessary. The uniqueness of banks, and not only in a crisis situation, should be recognized and the lessons drawn for the implementation of competition policy.

The competition-stability tradeoff also applies to emerging economies. An emerging market economy is characterized by high uncertainty, increased likelihood and incidence of financial and currency crises, predominant financial role of banks, and weak supervisory structure. These characteristics make it much more difficult to follow the developed country regulatory strategy. Emerging economies will tend to have a higher cost of liquidation of projects and social cost of failure, as well as a higher level of friction. The first two factors will push towards a tightening of the regulation while the higher friction may pull in the opposite direction. In emerging economies, optimal policy needs to carefully balance the impact of the different levels of friction and social cost of failure.

Merger policy in banking should be intertemporally consistent having in mind an optimal degree of concentration and dynamic incentives (rewarding prudence at the same time that entry is eased). An open issue is how to deal with TBTF institutions. In the US TBTF 
is not an antitrust issue while in the EU the competition authority controls distortions of competition which arise out of state aid and this has implications for TBTF. The credibility of the competition authority to impose conditions once an institution has been helped may provide a commitment device which has been seen lacking in bank bailouts. Controls on size are problematic because interconnectedness and line of business specialization are more important than size for systemic risk. With regard to the scope of the banking firm, conflict of interest is what leads to potential market failure and is the lead to indicate possible scope limitations.

All this calls for close collaboration of the regulator (in charge of stability and prudential control) and the competition authority (in charge of the health of competition). First of all, regulatory requirements and competition policy intensity have to be coordinated. Capital charges may have to be fine tuned to the intensity of competition in the different market segments. Second, a protocol of collaboration of the regulator and the competition authority should also be put forward. This will be particularly important in crisis situations. The competition authority has the potential to provide commitment to address TBTF problems that derive into competition distortions; the regulator should address the TBTF issue and moral hazard with systemic capital charges, effective resolution procedures, and scope restrictions which target conflicts of interest. Finally, crisis procedures should be established delineating liquidity help from recapitalization and the conditions for restructuring to avoid competitive distortions. Entities which are close to insolvency should be tightly regulated (and its activities restricted) in a prompt corrective action frame.

An open issue pertaining to the political economy of regulation is the debate over whether to let firms, banks in particular, get so large that have a decisive influence in regulation. 


\section{References}

Acharya, V., D. Gromb, and T. Yorulmazer (2009), "Imperfect Competition in the Interbank Market for Liquidity as a Rationale for Central Banking”, mimeo.

Allen, F. and D. Gale (1998), “Optimal Financial Crisis”, Journal of Finance, 53, 4, 1245-1284.

Allen, F. and D. Gale (2000), "Financial Contagion”, The Journal of Political Economy, $108,1,1-33$.

Allen, F. and D. Gale (2004), “Competition and Financial Stability”, Journal of Money, Credit and Banking, 26, 3, 453-480.

Allen, F. and A. Santomero (2001), “What Do Financial Intermediaries Do?”, Journal of Banking \& Finance, 25, 2, 271-294.

Alonso, I. (1996), “On Avoiding Bank Runs”, Journal of Monetary Economics, 37, 7387.

Baele, L., O. De Jonghe and R. Vander Vennet (2007), “Does the Stock Market Value Diversification?”, Journal of Banking and Finance, 32, 1820-1835.

Barth, J. R., D. E. Nolle, and T. N. Rice (1997), "Commercial Banking Structure, Regulation, and Performance: An International Comparison", Economic W.P. 97-6, Washington, D.C., Office of the Comptroller of the Currency.

Barth, J., G. Caprio and G. Levine (2004), "Bank Regulation and Supervision: What Works Best?”, Journal of Financial Intermediation, 13, 2, 205, 248.

Beck, T., A. Demiguc-Kunt and R. Levine (2006), "Bank Concentration and Crises”, Journal of Banking \& Finance, 30, 5, 1581-1603.

Berger, A., R. Demsetz and P. Strahan (1999), "The Consolidation of the Financial Services Industry: Causes, Consequences, and Implications for the Future”, Journal of Banking \& Finance, 23, 2-4, 135-194.

Berger, A., A. Kashyap and Scalise, J. (1995), “The Transformation of the U.S. Banking Industry: What a Long, Strange Trip It's Been”, Brookings Papers on Economic Activity, 2, 55-218. 
Berger, A., L. Klapper \& G. Udell (2001), "The Ability of Banks to Lend to Informationally Opaque Small Businesses”, Journal of Banking \& Finance, 25, 12, 2127-2167.

Berger, A., L. Klapper and R. Turk-Ariss (2009), "Bank Competition and Financial Stability”, Journal of Financial Services Research, 35, 2, 99-118.

Besanko, D. and A.V. Thakor (1993), "Relationship Banking, Deposit Insurance and Bank Portfolio”, in C. Mayer and X. Vives (eds.), Capital Markets and Financial Intermediation, Cambridge: Cambridge University Press, 292-318.

Boot, A.W. and S. Greenbaum (1993), "Bank Regulation, Reputation and Rents: Theory and Policy Implications”, in C. Mayer and X. Vives (eds.), Capital Markets and Financial Intermediation, Cambridge: Cambridge University Press, 262-285.

Boyd, J. H., and G. De Nicolò (2005), “The Theory of Bank Risk-taking and Competition Revisited”, Journal of Finance, 60, 3, 1329-1343.

Boyd, J.H., G. De Nicolò and A. Jalal (2009), "Bank Competition, Risk and Asset Allocations”, IMF Working Paper \#143.

Boyd, J.H., G. De Nicolò, and E. Loukoianova (2009), "Banking Crises and Crisis Dating: Theory and Evidence”, IMF Working Paper \#141.

Boyd, J.H. and M. Gertler (1993), "U.S. Commercial Banking: Trends, Cycles and Policy”, NBER Working Paper \#W4404.

Broecker, T. (1990), “Creditworthiness Tests and Interbank Competition”, Econometrica, $58,429-452$.

Brown, C. and S. Dinç (2009), "Too Many To Fail? Evidence of Regulatory Reluctance in Bank Failures when the Banking Sector is Weak", forthcoming in Review of Financial Studies.

Brunnermeier, M. and L. Pedersen, (2009), "Market Liquidity and Funding Liquidity", Review of Financial Studies, 22, 6, 2201-2238.

Bryant, J. (1980), "A Model of Reserves, Bank Runs, and Deposit Insurance?", Journal of Banking \& Finance, 4, 4, 335-344. 
Calomiris, C. and C. Kahn (1991), “The Role of Demandable Debt in Structuring Optimal Banking Arrangements”, American Economic Review, 81, 3, 497-513.

Caminal, R. J. Gual and X. Vives (1990), “Competition in Spanish Banking”, in European Banking in the 1990's, J. Dermine ed., Basil Blackwell.

Caminal, R. and C. Matutes (2002), “Market Power and Banking Failures”, International Journal of Industrial Organization, 20, 9, 1341-1361.

Caprio, G. and M. S. Martinez Peria (2002), “Avoiding Disaster: Policies to Reduce the Risk of Banking Crises”, in Monetary Policy and Exchange Rate Regimes, E. Cardoso and A. Galal (eds.), Cairo: The Egyptian Center for Economic Studies.

Carletti, E. and X. Vives (2009), "Regulation and Competition Policy in Banking”, in Competition Policy in the EU: Fifty Years On from the Treaty of Rome, X. Vives editor, Oxford University Press.

Chang, R. and A. Velasco (2001), "A Model of Financial Crises in Emerging Markets", The Quarterly Journal of Economics, 116, 2, 489-517.

Claessens, S. (2006), “Competitive Implications of Cross-Border Banking”, in: CrossBorder Banking: Regulatory Challenges (G. Caprio, D. Evanoff \& G. Kaufman eds.) Blackensack NJ: World Scientific Publishing, pp. 151-182.

Cole, H. and L. Ohanian (2004), "New Deal Policies and the Persistence of the Great Depression: A General Equilibrium Analysis”, Journal of Political Economy, 112, 4, 779-816.

Cordella, T. and L. Yeyati (2002), "Financial Opening, Deposit Insurance and Risk in a Model of Banking Competition”, European Economic Review, 46, 471-485.

Corsetti, G., B. Guimaraes and N. Roubini (2006), “International Lending of Last Resort and Moral Hazard: A Model of IMF’s Catalytic Finance”, Journal of Monetary Economics, 53, 3, 441-471.

Danthine, J.-P., F. Giavazzi, E.-L. von Thadden and X. Vives (1999), Monitoring European Integration: The Future of European Banking, CEPR, 1999, pp.118. 
De Jonghe, O. (2010), "The Impact of Revenue Diversity on Banking System Stability”, Journal of Financial Intermediation, forthcoming.

De Nicolò, G. and M. Kwast (2002), "Systemic Risk and Financial Consolidation: Are They Related?", Journal of Banking \& Finance, 26, 5, 861-880.

De Nicolò, G. and E. Loukoianova (2007), "Bank Ownership, Market Structure and Risk”, IMF Working Paper \#215.

Dell'Ariccia, G. (2001), “Asymmetric Information and the Structure of the Banking Industry”, European Economic Review, 45, 1957-1980.

Dell’Ariccia, G., E. Friedman and R. Marquez (1999), “Adverse Selection as Barrier to Entry in the Banking Industry", RAND Journal of Economics, 30, 515-534.

Dell'Ariccia, G., D. Igan and L. Laeven (2008), "Credit Booms and Lending Standards: Evidence from the Subprime Mortgage Market", International Monetary Fund Working Paper \# 08/106.

Demirgüç-Kunt, A. and E. Detragiache (1998), "The Determinants of Banking Crises: Evidence from Developing and Developed Countries”, IMF Staff Papers, 45, 1, 81109.

Demirgüç-Kunt, A. and E. Detragiache (2001), "Financial Liberalization and Financial Fragility”, in Financial Liberalization: How Far, How Fast?, G. Caprio, P. Honohan and J. Stiglitz (eds.), Cambridge: Cambridge University Press.

Demirgüç-Kunt, A., and H. Huizinga (2010), "Bank Activity and Funding Strategies”, Journal of Financial Economics, forthcoming.

Demsetz, R., M. Saidenberg and P. Strahan (1996), "Banks with Something to Lose: The Disciplinary Role of Franchise Value”, Federal Reserve Bank of New York Economic Policy Review, 2, 2, 1-14.

Demsetz, R. and P. Strahan (1997), "Diversification, Size and Risk at Bank Holding Companies”, Journal of Money, Credit \& Banking, 29, 3, 300-313.

Detragiache, E., T. Tressel \& P. Gupta (2008), "Foreign Banks in Poor Countries: Theory and Evidence”, Journal of Finance, 63, 5, 2123-2160. 
Dewatripont, M., and J. Tirole (1994), The Prudential Regulation of Banks, Cambridge: MIT Press.

Diamond, D. (1984), "Financial Intermediation and Delegated Monitoring”, Review of Economic Studies 51, 393-414.

Diamond, D. and P. Dybvig (1983), "Bank Runs, Deposit Insurance, and Liquidity”, Journal of Political Economy, 91, 401-419.

Diamond, D. and R. Rajan (2001), "Liquidity Risk, Liquidity Creation, and Financial Fragility: A Theory of Banking”, Journal of Political Economy, 109, 2, 287-327.

Dick, A. (2007), "Market Size, Service Quality and Competition in Banking”, Journal of Money, Credit \& Banking, 39, 1, 49-81.

Edwards, F. and F. Mishkin (1995), "The Decline of Traditional Banking: Implications for Financial Stability and Regulatory Policy”, Economic Policy Review, 1, 2, 3745.

Ennis, H. and T. Keister (2009), "Bank Runs and Institutions: The Perils of Intervention”, American Economic Review, 99, 4, 1588-1607.

Gale, D. and X. Vives (2002), "Dollarization, Bailouts, and the Stability of the Banking System”, Quarterly Journal of Economics, 117, 2, 467-502.

Galloway, T., W. Lee and D. Roden (1997), "Banks' Changing Incentives and Opportunities for Risk Taking”, Journal of Banking \& Finance, 21, 4, 509-527.

Garratt, R. and T. Keister (2009), "Bank Runs as Coordination Failures: An Experimental Study”, Journal of Economic Behavior \& Organization, 71, 300-317.

Gehrig, T. (1998), "Screening, Cross-Border Banking and the Allocation of Credit", Research in Economics, 52, 4, 387-407.

Goldstein, I. and A. Pauzner (2005), "Demand Deposit Contracts and the Probability of Bank Runs”, Journal of Finance, 60, 3, 1293-1328.

Gorton, G. (1985), "Bank Supervision of Convertibility”, Journal of Monetary Economics, 15, 177-193. 
Gorton, G. (1988), “Banking Panics and Business Cycles”, Oxford Economic Papers, 40, 751-781.

Group of Ten (2001), Report on Consolidation in the Financial Sector, available at www.bis.org, Basel: Group of Ten.

Hau, H. and M. Thum (2009), “The Subprime Crisis and Board (In-)Competence: Evidence Private vs Public Banks in Germany”, Economic Policy, 60, 701 - 752.

Hoshi, T. and A. Kashyap (2000), "The Japanese Banking Crisis: Where Did It Come From and How Will It End?", NBER Chapters, in NBER Macroeconomics Annual 1999, 14, 129-212.

Hellman, T.F., K. Murdock and J. Stiglitz (2000), "Liberalization, Moral Hazard in Banking and Prudential Regulation: Are Capital Requirements Enough?”, American Economic Review, 90, 1, 147-165.

Holmstrom, B., and J. Tirole (1997), “Financial Intermediation, Loanable Funds and the Real Sector”, Quarterly Journal of Economics, 112, 663-691.

Holmstrom, B., and J. Tirole (1998), “Private and Public Supply of Liquidity”, Journal of Political Economy, 106, 1, 1-40.

Honkapohja, S. (2009), “The 1990’s Financial Crises in Nordic Countries”, Bank of Finland Research Papers 5.

Hughes, J.P., W. Lang, L. Mester and C.G. Moon (1996), "Efficient Banking under Interstate Branching”, Journal of Money, Credit \& Banking, 28, 4, 1046-1071.

Hughes, J.P., W. Lang, L. Mester and C.G. Moon (1998), “The Dollars and Sense of Bank Consolidation”, Federal Reserve Bank of Philadelphia Working Paper \#98-10.

Jacklin, C. and S. Bhattacharya (1988), "Distinguishing Panics and Information-Based Bank Runs: Welfare and Policy Implications”, Journal of Political Economy, 96, 3, 568-592.

Jayaratne, J. and P. Strahan (1998), “Entry Restrictions, Industry Evolution, and Dynamic Efficiency: Evidence from Commercial Banking”, Journal of Law and Economics, 61, 239-275. 
Keeley, M. (1990), "Deposit Insurance, Risk and Market Power in Banking”, American Economic Review, 80, 1183-1200.

Kroszner, R. and P. Strahan (1999), "What Drives Deregulation? Economics and Politics of the Relaxation of Bank Branching Restrictions", Quarterly Journal of Economics, 114, 4, 1436-1467.

Madies, P. (2006), “An Experimental Exploration of Self-fulfilling Banking panics: Their Occurrence, Persistence, and Prevention”, Journal of Business, 79, 1831-1866.

Martinez-Miera, D. and R. Repullo (2008), "Does Competition Reduce the Risk of Bank Failure?”, mimeo.

Matutes, C. and X. Vives (1996), "Competition for Deposits, Fragility, and Insurance”, Journal of Financial Intermediation, 5, 184-216.

Matutes, C. and X. Vives (2000), "Imperfect Competition, Risk Taking and Regulation in Banking”, European Economic Review 44, 1, 1-34.

Morris, S. and H. Shin (1998), "Unique Equilibrium in a Model of Self-fulfilling Currency Attacks”, American Economic Review, 88, 587-597.

Morris, S. and H. Shin (2002), "The Social Value of Public Information”, American Economic Review, 92, 1521-1534.

Morris, S. and H. Shin (2004), "Coordination Risk and the Price of Debt”, European Economic Review, 48, 1, 133-153.

Perotti, E. and J. Suárez (2002), "Last Bank Standing: What Do I Gain if You Fail?”, European Economic Review, 46, 9, 1599-1622.

Petersen, M and R. Rajan (1994), "The Benefits of Lending Relationships: Evidence from Small Business Data”, Journal of Finance, 49, 1, 3-37.

Petersen, M. and R. Rajan (1995), "The Effect of Credit Market Competition on Lending Relationships”, Quarterly Journal of Economics, 110, 407-443.

Postlewaite, A. and X. Vives (1987), "Bank Runs as a Equilibrium Phenomenon”, Journal of Political Economy, 95, 3, 487-491. 
Ratnovski, L. and R. Huang (2009), “Why are Canadian Banks More Resilient?”, IMF working paper, 09/152.

Reinhart, C. and K. Rogoff (2008a), “Banking Crises, An Equal Opportunity Menace”, NBER W.P. \# 14587.

Reinhart, C. and K. Rogoff (2008b), “This Time is Different: A Panoramic View of Eight Centuries of Financial Crises”, NBER W.P. \#13882.

Repullo, R. (2004), “Capital Requirements, Market Power and Risk-Taking in Banking”, Journal of Financial Intermediation, 13, 156-182.

Riordan, M. (1993), “Competition and Bank Performance: A Theoretical Perspective”, in C. Mayer and X. Vives (eds.), Capital Markets and Financial Intermediation, Cambridge: Cambridge University Press, 328-343.

Rochet, J.C. and X. Vives (2004), “Coordination Failures and the Lender of Last Resort: Was Bagehot Right After All?”, Journal of the European Economic Association, 2, 1116-1147.

Sáez, L. and X. Shi (2004), "Liquidity Pools, Risk Sharing, and Financial Contagion", Journal of Financial Services Research, 25, 1, 5-23.

Salas, V. and J. Saurina (2003), "Deregulation, Market Power and Risk Behaviour in Spanish Banks”, European Economic Review, 47, 1061-1075.

Saurina, J., G. Jiménez and J. López (2007), “How Does Competition Impact Bank Risk Taking?”, Federal Reserve Bank of San Francisco Working Paper \#23.

Schaeck, K., M. Cihak and S. Wolfe (2009), "Are Competitive Banking Systems More Stable?", Journal of Money, Credit \& Banking, 41, 4, 711-734.

Schildbach, J. (2009), “Global Banking Trends After the Crisis”, Deutsche Bank Euromonitor \#67.

Shehzad, C. T. and J. De Haan (2009), “Financial Liberalization and Banking Crises”, mimeo.

Smith, B. (1984), “’”Private Information, Deposit Interest Rates, and the 'Stability’ of the Banking System”, Journal of Monetary Economics, 14, 293-317. 
Vives, X. (2000), “Lessons from European Banking Liberalization and Integration”, in The Internationalization of Financial Services, S. Claessens and M. Jansen (eds.), London: Kluwer Law International, 177-198.

Vives, X. (2001), "Competition in the Changing World of Banking", Oxford Review of Economic Policy, 17, 4, 535-547.

Vives, X. (2005), “Complementarities and Games: New Developments”, Journal of Economic Literature, 43, 437-479.

Vives, X. (2006), "Banking and Regulation in Emerging Markets”, The World Bank Research Observer, 21, 2, 2006, 179-206.

Vives, X. (2009), “Asset Auctions, Information and Liquidity”, Journal of the European Economic Association, forthcoming.

Vives, X. (2010a), “Stress, Crises and Policy”, mimeo.

Vives, X. (2010b), "Competition Policy in Banking after the Crisis: A New World Ahead?”, mimeo.

White, L. (2009), "Financial Regulation and the Current Crisis: A Guide for the Antitrust Community", mimeo. 